ARTICLE

\title{
Exploiting two-dimensional morphology of molybdenum oxycarbide to enable efficient catalytic dry reforming of methane
}

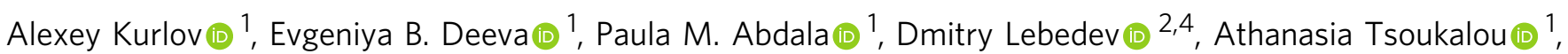
Aleix Comas-Vives (10 ${ }^{3 凶}$, Alexey Fedorov (1) ${ }^{1 凶} \&$ Christoph R. Müller (i) ${ }^{1 凶}$

The two-dimensional morphology of molybdenum oxycarbide (2D- $\mathrm{Mo}_{2} \mathrm{CO}_{x}$ ) nanosheets dispersed on silica is found vital for imparting high stability and catalytic activity in the dry reforming of methane. Here we report that owing to the maximized metal utilization, the specific activity of $2 \mathrm{D}-\mathrm{Mo}_{2} \mathrm{CO}_{x} / \mathrm{SiO}_{2}$ exceeds that of other $\mathrm{Mo}_{2} \mathrm{C}$ catalysts by ca. 3 orders of magnitude. $2 \mathrm{D}-\mathrm{Mo}_{2} \mathrm{CO}_{x}$ is activated by $\mathrm{CO}_{2}$, yielding a surface oxygen coverage that is optimal for its catalytic performance and a Mo oxidation state of ca. +4 . According to ab initio calculations, the DRM proceeds on Mo sites of the oxycarbide nanosheet with an oxygen coverage of 0.67 monolayer. Methane activation is the rate-limiting step, while the activation of $\mathrm{CO}_{2}$ and the $\mathrm{C}-\mathrm{O}$ coupling to form $\mathrm{CO}$ are low energy steps. The deactivation of $2 \mathrm{D}-\mathrm{Mo}_{2} \mathrm{CO}_{x} / \mathrm{SiO}_{2}$ under DRM conditions can be avoided by tuning the contact time, thereby preventing unfavourable oxygen surface coverages.

\footnotetext{
${ }^{1}$ Department of Mechanical and Process Engineering, ETH Zürich, Leonhardstrasse 21, CH 8092 Zürich, Switzerland. ${ }^{2}$ Department of Chemistry and Applied Biosciences, ETH Zürich, Vladimir-Prelog-Weg 1-5, CH 8093 Zürich, Switzerland. ${ }^{3}$ Department of Chemistry, Universitat Autònoma de Barcelona, 08193 Cerdanyola del Vallès, Catalonia, Spain. ${ }^{4}$ Present address: Department of Materials Science and Engineering, Northwestern University, Evanston, IL 60208, USA.『email: Aleix.Comas@uab.cat; fedoroal@ethz.ch; muelchri@ethz.ch
} 
S ince the early work by Sinfelt ${ }^{1}$ and Boudart ${ }^{2}$ demonstrated that $\mathrm{Mo}_{2} \mathrm{C}$ and WC exhibit platinum-like catalytic activity in alkane hydrogenolysis and isomerization, a multitude of reports has appeared aiming to exploit molybdenum carbide for industrially-relevant reactions such as methane aromatization ${ }^{3,4}$, the water-gas shift ${ }^{5,6}$, and $\mathrm{CO}_{2}$ hydrogenation reactions ${ }^{7,8}$, to name just a few ${ }^{9}$. In contrast to middle-to-late transition metalbased catalysts that deactivate by the deposition of coke, sintering or poisoning ${ }^{10}$, carbide catalysts typically feature a low rate of coking $^{11}$, are resistant to high temperature sintering as well as to sulfur poisoning ${ }^{12,13}$. However, the high oxophilicity of carbides fosters their evolution in reactions with oxygenate substrates, leading ultimately to deactivation via the formation of oxide phases; deactivated catalysts require regeneration by recarburization with $\mathrm{CH}_{4} / \mathrm{H}_{2}{ }^{11}$. If such deactivation pathways are avoided while the metal utilization of carbides is maximized, for instance by developing catalysts with a high surface-to-bulk ratio and a high dispersion on supports, the replacement of traditional, more expensive middle-to-late transition metal catalysts by carbide-based catalysts will become viable.

The dry reforming of methane, (DRM, $\mathrm{CH}_{4}+\mathrm{CO}_{2} \leftrightarrow 2 \mathrm{CO}+$ $2 \mathrm{H}_{2}$ ) is an example of a particularly challenging reaction for $\mathrm{Mo}_{2} \mathrm{C}$-based catalysts because it combines a $\mathrm{CO}_{2}$-rich feed with high operating temperatures (typically, $800{ }^{\circ} \mathrm{C}$ and above) ${ }^{11,14-21}$. Deactivation of $\mathrm{Mo}_{2} \mathrm{C}$ in DRM conditions proceeds oxidatively according to $\mathrm{Mo}_{2} \mathrm{C}+5 \mathrm{CO}_{2} \rightarrow 2 \mathrm{MoO}_{2}+6 \mathrm{CO}^{11,17,18}$ and in order to mitigate it, dry reforming of methane is often conducted at elevated pressures $(2-10 \mathrm{bar})^{11,14,16,18,21}$. From a mechanistic standpoint, an ill-defined molybdenum oxycarbide phase $\left(\mathrm{MoO}_{x} \mathrm{C}_{y}\right)$ has been reported to play a key role in $\mathrm{DRM}^{22}$, as well as in the water-gas shift ${ }^{23}$, deoxygenation ${ }^{24,25}$, and $\mathrm{CO}_{2}$-tomethanol ${ }^{8}$ conversion processes, suggesting that the partial oxidation of $\mathrm{Mo}_{2} \mathrm{C}$ is favorable for those reactions. In addition, recent reports on $\mathrm{CO}_{2}$-propane dehydrogenation catalyzed by $\mathrm{Mo}_{2} \mathrm{C}$ highlighted that control over the oxygen coverage of the surface oxycarbide layer allows tuning the catalytic activity and selectivity ${ }^{26,27}$. Molybdenum oxycarbide species were also proposed as intermediates during the dehydroaromatization of methane on molybdenum-loaded zeolite ZSM- ${ }^{28}$. However, establishing the local structure and the nature of the active sites in such molybdenum oxycarbide phases has remained challenging, largely because well-defined oxycarbide catalysts, serving as references, are not available.

In this context, a recently discovered family of twodimensional atomically-thin early transition metal carbides, nitrides, and carbonitrides called MXenes ${ }^{29}$ could be exploited as an entry point to supported well-defined 2D carbides and oxycarbides. MXene films are nanocrystalline yet form stable colloidal solutions in protic solvents, and feature metal-terminated surfaces (vide infra) with a lateral size in the submicron scale, which yields highly uniform surface metal sites ${ }^{30}$. The atomically thin nature of MXenes enables optimal metal utilization provided that these films are highly dispersed on a support. The $2 \mathrm{D}$ morphology is also advantageous for mechanistic studies since bulk metal sites in catalysts derived from MXenes, are minimized. Therefore, the characterization methods applied (even when not being inherently surface sensitive) will provide information mostly about the surface sites, which is instructive for structureactivity studies.

In what follows, we describe an approach to yield a supported two-dimensional (2D) model molybdenum oxycarbide material containing well-defined surface sites that are highly active in the dry reforming of methane. We prepare this catalyst from colloidal, delaminated thin films of the molybdenum carbide MXene phase, $\mathrm{Mo}_{2} \mathrm{CT}_{x}$, where $T$ stands for $\mathrm{OH}, \mathrm{O}, \mathrm{F}$ surface termination groups. After supporting $\mathrm{Mo}_{2} \mathrm{CT}_{x}$ on $\mathrm{SiO}_{2}$, these surface groups can be controllably removed (de-functionalized) by reduction in $\mathrm{H}_{2}$, giving $2 \mathrm{D}-\mathrm{Mo}_{2} \mathrm{C} / \mathrm{SiO}_{2}$. The oxidation of $2 \mathrm{D}-\mathrm{Mo}_{2} \mathrm{C} / \mathrm{SiO}_{2}$ by $\mathrm{CO}_{2}$ at $800^{\circ} \mathrm{C}$ gives a $2 \mathrm{D}$ molybdenum oxycarbide $2 \mathrm{D}-\mathrm{Mo}_{2} \mathrm{CO}_{x} /$ $\mathrm{SiO}_{2}$ with a high oxygen surface coverage and an average Mo oxidation state of +5.5 . Subjecting this material to DRM conditions reduces the oxygen coverage and forms a catalyst in situ with an average Mo oxidation state of +4 . This material is highly active in DRM, in contrast to fully reduced $2 \mathrm{D}-\mathrm{Mo}_{2} \mathrm{C} / \mathrm{SiO}_{2}$ and $2 \mathrm{D}-\mathrm{Mo}_{2} \mathrm{CO}_{x} / \mathrm{SiO}_{2}$ material with highest oxygen coverage (confirmed by a Mo oxidation state of ca. +5 ) which are essentially inactive for the DRM. Our Mo $K$-edge X-ray absorption near edge structure (XANES) and X-ray photoelectron spectroscopy (XPS) results verify that molybdenum oxycarbide is the active phase in $\mathrm{Mo}_{2} \mathrm{C}$-based DRM catalysts ${ }^{31}$ and density functional theory (DFT) calculations identify that an oxygen coverage of ca. 0.7 monolayer provides a high activity of $2 \mathrm{D}-\mathrm{Mo}_{2} \mathrm{CO}_{x} / \mathrm{SiO}_{2}$ in DRM. Reducing or increasing this optimal oxygen coverage decreases the reaction rate. $2 \mathrm{D}-\mathrm{Mo}_{2} \mathrm{CO}_{x} / \mathrm{SiO}_{2}$ catalyst with reduced oxygen coverage is also less selective owing to a competing reverse water-gas shift reaction. Hence, supported 2D$\mathrm{Mo}_{2} \mathrm{CO}_{x}$ catalyst with an initially high coverage of surface oxygen atoms activates first by reduction, that is the oxygen coverage is lowered until a maximum in DRM performance is reached at a Mo oxidation state of ca. +4 . Reducing the Mo oxidation state further (i.e., lowering the oxygen coverage below ca. 0.7 monolayers) leads to catalyst deactivation. This observation is in sharp contrast to non-layered $\mathrm{Mo}_{2} \mathrm{C}$-based catalysts that readily deactivate by oxidation in a $\mathrm{CO}_{2}$ atmosphere. It is therefore remarkable that deactivated $2 \mathrm{D}-\mathrm{Mo}_{2} \mathrm{CO}_{x} / \mathrm{SiO}_{2}$ catalysts do not contain any deposited coke according to temperatureprogrammed oxidation (TPO) experiments and can be regenerated by oxidation in $\mathrm{CO}_{2}$, fully recovering their highest catalytic activity. Noteworthy, the deactivation of $2 \mathrm{D}-\mathrm{Mo}_{2} \mathrm{CO}_{x} / \mathrm{SiO}_{2}$ under DRM conditions can be avoided by optimizing the contact time. Density functional theory calculations corroborate experimental observations and demonstrate that the DRM pathway on an oxycarbidic surface with a submonolayer oxygen coverage is energetically favored compared to the pathway occurring on a fully carbidic surface. The fully oxygen-covered surface is unstable in DRM conditions and reduces in situ its oxygen coverage below 1 oxygen monolayer, also consistent with our experiments.

\section{Results}

Synthesis and characterization. Multi-layered $\mathrm{Mo}_{2} \mathrm{CT}_{x}{ }^{32}$ (referred to as $m-\mathrm{Mo}_{2} \mathrm{C} T_{x}$ ) was sonicated in ethanol to yield, after centrifugation, a transparent purple colloidal solution of delaminated 2D- $-\mathrm{Mo}_{2} \mathrm{CT}_{x}$ flakes (Fig. 1a and Supplementary Fig. 2) ${ }^{33}$. A dried aliquot of this solution was analyzed by transmission electron microscopy (TEM) revealing single and a few-layer thin flakes of $\mathrm{Mo}_{2} \mathrm{CT}_{x}$, the latter morphology is identified by the characteristic scrolling of edges of the few-layer thin MXene nanosheets (Supplementary Fig. 3 ) $^{34}$. The X-ray powder diffraction pattern of the dried delaminated material is typical of a layered $\mathrm{Mo}_{2} \mathrm{CT}_{x}$ structure (Supplementary Fig. 4) ${ }^{35}$. The colloidal solution of the $\mathrm{Mo}_{2} \mathrm{CT}_{x}$ nanoflakes (ca. $0.15 \mathrm{mg} \mathrm{mL}^{-1}$ concentration determined by thermogravimetric analysis) was used for several consecutive incipient wetness impregnations of a $\mathrm{SiO}_{2}$ support (Aerosil 300 , calcined at $950{ }^{\circ} \mathrm{C}, 194 \mathrm{~m}^{2} \mathrm{~g}^{-1}$ surface area according to nitrogen physisorption), giving $2 \mathrm{D}-\mathrm{Mo}_{2} \mathrm{CT}_{x} / \mathrm{SiO}_{2}$ that, after drying at $100^{\circ} \mathrm{C}$ in air, contained $0.48 \mathrm{wt} \%$ Mo by elemental analysis. TEM imaging of $2 \mathrm{D}-\mathrm{Mo}_{2} \mathrm{CT}_{x} / \mathrm{SiO}_{2}$ shows agglomerated amorphous silica grains that are homogeneously covered with thin $\mathrm{Mo}_{2} \mathrm{C} T_{x}$ nanosheets (Fig. $1 \mathrm{~b}$ and Supplementary Fig. 5). Consistent with an MXene structure, hexagonally 


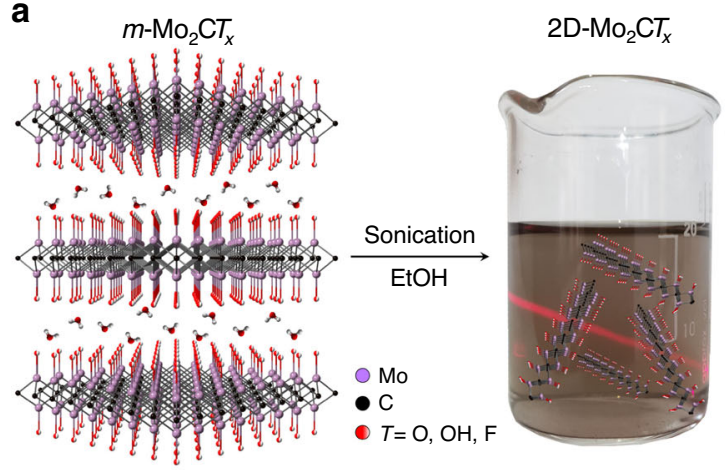

b

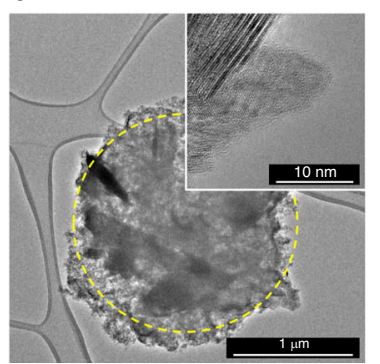

C

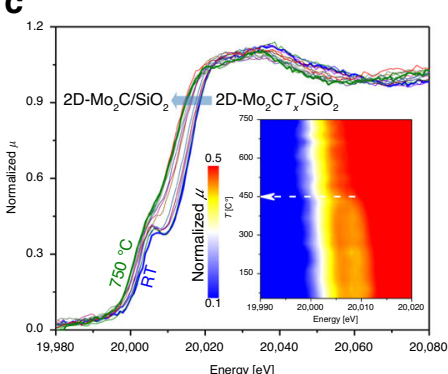

$2 \mathrm{D}-\mathrm{Mo}_{2} \mathrm{CT}_{x} / \mathrm{SiO}_{2}$

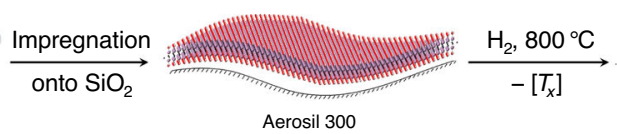

d

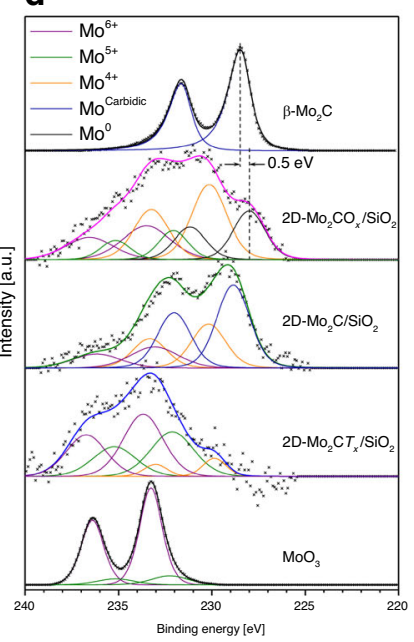

$2 \mathrm{D}-\mathrm{Mo}_{2} \mathrm{C} / \mathrm{SiO}_{2}$
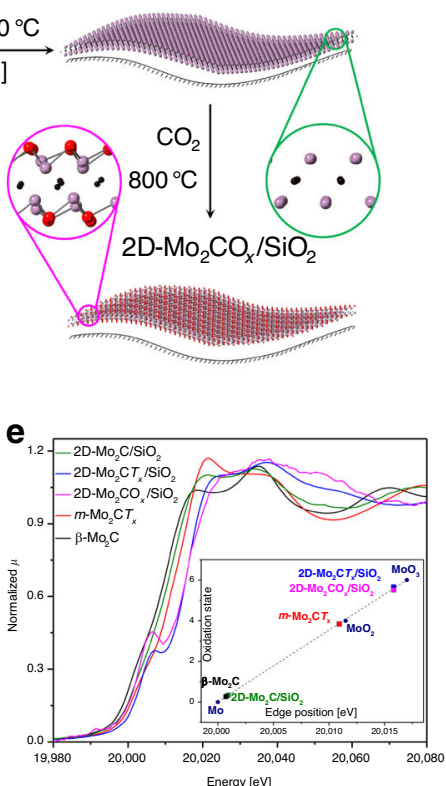

Fig. 1 Synthesis and characterization of $\mathbf{2 D}-\mathbf{M o}_{\mathbf{2}} \mathbf{C O} \mathbf{O}_{\mathbf{x}} / \mathbf{S i O}_{\mathbf{2}}$. a Synthesis of $2 \mathrm{D}-\mathrm{Mo}_{2} \mathrm{CO}_{x} / \mathrm{SiO}_{2}$ from delaminated $\mathrm{Mo}{ }_{2} \mathrm{CT} T_{x}$ films via incipient wetness impregnation of their colloidal solution onto silica, followed by the reduction of the $T_{x}$ groups under $\mathrm{H}_{2}\left(\mathrm{giving} 2 \mathrm{D}-\mathrm{Mo}_{2} \mathrm{C} / \mathrm{SiO} 2\right)$ and the subsequent oxidation in $\mathrm{CO}_{2}$ (giving $2 \mathrm{D}-\mathrm{Mo}_{2} \mathrm{CO}_{x} / \mathrm{SiO}_{2}$ ); $\mathbf{b}$ TEM images of $2 \mathrm{D}-\mathrm{Mo}_{2} \mathrm{CT}_{\mathrm{x}} / \mathrm{SiO}_{2}$; $\mathbf{c}$ in situ reduction of $2 \mathrm{D}-\mathrm{Mo}_{2} \mathrm{CT} / \mathrm{SiO} 2$ under $\mathrm{H}_{2}$ as followed by $\mathrm{Mo} \mathrm{K}$-edge $\mathrm{XANES}$ revealing an evolution of the pre-edge feature with temperature (shown in the inset as a contour plot); $\mathbf{d}$ oxidation state of Mo in reference and synthesized materials determined from the deconvolution of ex situ XPS data of the Mo $3 d$ core levels as well as from e the edge position in XANES spectra.

Table 1 EXAFS fitting of $2 \mathrm{D}-\mathrm{MO}_{2} \mathrm{CT}_{x} / \mathrm{SiO}_{2}$ (R factor 0.008).

\begin{tabular}{lllll} 
Shell & $\mathbf{C N}$ & $\mathbf{R}(\mathbf{A})$ & $\mathbf{\sigma}^{\mathbf{2}}\left(\mathbf{A}^{\mathbf{2}}\right)$ & $\mathbf{\Delta E}(\mathbf{e V})$ \\
\hline $\mathrm{Mo}-\mathrm{O}_{1}$ & $1.0(2)$ & $1.74(1)$ & $0.005(2)$ & $6(2)$ \\
$\mathrm{Mo}-\mathrm{C} / \mathrm{O}_{2}$ & $1.2(3)$ & $2.03(1)$ & & \\
$\mathrm{Mo}-\mathrm{Mo}_{1}$ & $0.8(4)$ & $2.63(1)$ & $0.006(2)$ & \\
$\mathrm{Mo}-\mathrm{Mo}_{2}$ & $1.4(5)$ & $2.92(2)$ & & \\
$\mathrm{Mo}-\mathrm{Mo}_{3}$ & $1.1(4)$ & $3.42(2)$ & & \\
\hline
\end{tabular}

ordered Mo atoms are observed by (high resolution) HR-TEM in $2 \mathrm{D}-\mathrm{Mo}_{2} \mathrm{CT}_{x} / \mathrm{SiO}_{2}$ (Supplementary Fig. 5). The X-ray powder diffraction (XRD) pattern of $2 \mathrm{D}-\mathrm{Mo}_{2} \mathrm{CT}_{x} / \mathrm{SiO}_{2}$ reveals only an amorphous halo corresponding to $\mathrm{SiO}_{2}$ (Supplementary Fig. 6). The absence of crystalline peaks of $m-\mathrm{Mo}_{2} \mathrm{C} T_{x}$ confirms a high dispersion of individual delaminated $\mathrm{Mo}_{2} \mathrm{CT}_{x}$ nanosheets on the support.

Next, we fitted the experimentally acquired Fouriertransformed Mo K-edge extended X-ray absorption fine structure (EXAFS) functions of $2 \mathrm{D}-\mathrm{Mo}_{2} \mathrm{CT}_{x} / \mathrm{SiO}_{2}$ with two coordination spheres, i.e., $\mathrm{Mo}-\mathrm{C} / \mathrm{O} / \mathrm{OH}$ and $\mathrm{Mo}-\mathrm{Mo}$. The fitting of the first coordination sphere of Mo gives two scattering paths with interatomic distances of 1.74(1) and 2.03(1) $\AA$ and coordination numbers $(\mathrm{CN})$ of $1.0(2)$ and $1.2(3)$, respectively (Table 1 , Supplementary Fig. 12). The shorter scattering path is attributed to molybdenum oxo $(\mathrm{Mo}=\mathrm{O})$ surface sites since the fitted distance $1.74(1) \AA$ is in good agreement with the reported $\mathrm{Mo}=\mathrm{O}$ bond lengths of ca. $1.7 \AA$ found in a molybdenum oxycarbide in a zeolite structure ${ }^{31}$ as well as in molecular Mo complexes ${ }^{36,37}$ (determined by EXAFS and X-Ray crystallography, respectively). The second scattering path of the first coordination shell with an interatomic distance of 2.03(1) $\AA$ is attributed to the Mo-C and
Mo-O bonds where $\mathrm{O}$ belongs to a hydroxy surface termination site and $\mathrm{C}$ is the interlayer carbidic carbon, consistent with the $2.1 \AA \mathrm{Mo}-\mathrm{C}$ distance in the parent $m-\mathrm{Mo}_{2} \mathrm{CT}_{x}{ }^{32}$. The second Mo coordination sphere is fitted with three Mo-Mo scattering paths with interatomic distances of 2.63(1), 2.92(2), and 3.42(2) $\AA$ and with coordination numbers of $0.8(4), 1.4(5)$, and 1.1(4), respectively (Table 1, Supplementary Fig. 12). The presence of three different Mo-Mo paths indicates a strong distortion of Mo sites in silica-supported $\mathrm{Mo}_{2} \mathrm{CT}_{x}$, deviating notably from the Mo coordination environment in parent $m-\mathrm{Mo}_{2} \mathrm{CT}_{x}$ that features only two Mo-Mo paths at $2.9 \AA$ and $3.2 \AA$ with coordination numbers of 4 and 2, respectively (as determined by EXAFS) ${ }^{32}$. This deviation is likely owing to (i) the higher fraction of $\mathrm{Mo}=\mathrm{O}$ sites in $2 \mathrm{D}-\mathrm{Mo}_{2} \mathrm{CT} T_{x} / \mathrm{SiO}_{2}$ relative to the $m-\mathrm{Mo}_{2} \mathrm{CT} T_{x}$, (ii) a disorder of $2 \mathrm{D}-\mathrm{Mo}_{2} \mathrm{CT}_{x} / \mathrm{SiO}_{2}$ caused by the geometrical curvature of the delaminated nanosheets supported on the silica grains and (iii) the interaction with the support. All these factors could contribute to the lower total CNs of $\mathrm{Mo}$ in $2 \mathrm{D}-\mathrm{Mo}_{2} \mathrm{CT}_{x} / \mathrm{SiO}_{2}$ as determined by EXAFS.

Subsequently, we explored the transformation of these silicasupported $2 \mathrm{D}-\mathrm{Mo}_{2} \mathrm{CT}$ 列 sheets in reductive, oxidative, and DRM conditions. Note that, unless specified otherwise, all these treated materials were characterized by avoiding exposure to air, using in situ experimentation, gloveboxes and air-tight transfers for characterization (XPS, fourier-transform infrared (FTIR) spectroscopy, TEM and XANES). Reductive de-functionalization of 2D$\mathrm{Mo}_{2} \mathrm{CT}_{x} / \mathrm{SiO}_{2}$ from the passivating $T_{x}$ surface groups was first studied in $\mathrm{H}_{2}$ flow by in situ XANES (Mo K-edge, Fig. 1c). Interestingly, in contrast to the bulk $\mathrm{Mo}_{2} \mathrm{CT}_{x}{ }^{32}$, a well-defined pre-edge feature, typical for molybdenum in a noncentrosymmetric environment ${ }^{38,39}$, appears in the room temperature XANES spectrum of $2 \mathrm{D}-\mathrm{Mo}_{2} \mathrm{CT} T_{x} / \mathrm{SiO}_{2}$ (Supplementary Fig. 13). Under $\mathrm{H}_{2}$ flow and with increasing temperature (in situ 
XANES experiment), the Mo $K$-edge in $2 \mathrm{D}-\mathrm{Mo}_{2} \mathrm{CT}_{x} / \mathrm{SiO}_{2}$ shifts to lower energies and this process continues up to ca. $450{ }^{\circ} \mathrm{C}$ (from 20015.8 to $20002.0 \mathrm{eV}$ ), indicating a gradual reduction of Mo due to the de-functionalization of the $T_{x}$ groups (Fig. 1c). Simultaneously, the intensity of the characteristic pre-edge feature of $2 \mathrm{D}-\mathrm{Mo}_{2} \mathrm{CT}_{x} / \mathrm{SiO}_{2}$ reduces until its disappearance at ca. $450{ }^{\circ} \mathrm{C}$. Increasing the temperature further to $750{ }^{\circ} \mathrm{C}$ induces only a minor shift of the Mo $K$-edge position compared to $450{ }^{\circ} \mathrm{C}$, that is from 20002.0 to $20000.8 \mathrm{eV}$, the latter value is very close to the edge position of $\beta-\mathrm{Mo}_{2} \mathrm{C}(20000.7 \mathrm{eV})$. This suggests that $\mathrm{H}_{2}$ treatment at $750{ }^{\circ} \mathrm{C}$ leads to a Mo terminated carbidic surface predominantly free from oxo, hydroxy and fluoro terminations, supporting the assignment of the aforementioned pre-edge feature to molybdenum sites in $2 \mathrm{D}-\mathrm{Mo}_{2} \mathrm{CT}_{x} / \mathrm{SiO}_{2}$ as opposed to $\mathrm{MoO}_{2}$ or $\mathrm{MoO}_{3}$ (conceivable oxidation products of $2 \mathrm{D}-\mathrm{Mo}_{2} \mathrm{CT}_{x}$ ). Noteworthy, the temperature for the de-functionalization of most of the $T_{x}$ groups in $2 \mathrm{D}-\mathrm{Mo}_{2} \mathrm{CT}_{x} / \mathrm{SiO}_{2}$ (according to XANES) is approximately $450{ }^{\circ} \mathrm{C}$, which is $150{ }^{\circ} \mathrm{C}$ lower than that of $\mathrm{m}$ $\mathrm{Mo}_{2} \mathrm{CT}_{x}{ }^{32}$, probably owing to the high dispersion of the $2 \mathrm{D}$ $\mathrm{Mo}_{2} \mathrm{CT}_{x}$ sheets on the silica surface that eliminates gas diffusion limitations in the pores of $m-\mathrm{Mo}_{2} \mathrm{CT}_{x}$.

Since the DRM reaction typically requires high temperatures to yield high equilibrium conversions $\left(>700^{\circ} \mathrm{C}\right)^{40}, 2 \mathrm{D}-\mathrm{Mo}_{2} \mathrm{CT}_{x} / \mathrm{SiO}_{2}$ was treated in a $\mathrm{H}_{2}$ flow at $800^{\circ} \mathrm{C}$ for $1 \mathrm{~h}$ to obtain $2 \mathrm{D}-\mathrm{Mo}_{2} \mathrm{C} /$ $\mathrm{SiO}_{2}$. This high temperature, reductive treatment did not affect significantly the original morphology and high dispersion of the silica-supported nanosheets, as confirmed by TEM imaging (Supplementary Fig. 8). That said, in few cases small nanoparticles (ca. 2-3 nm) decorating molybdenum carbide sheets could be discerned in TEM images (Supplementary Fig. 8) possibly due to the partial sintering of $2 \mathrm{D}-\mathrm{Mo}_{2} \mathrm{C}$ sheets to $\mathrm{Mo}_{2} \mathrm{C}$ nanoparticles at areas where nanosheets overlap. Overall, $2 \mathrm{D}-\mathrm{Mo}_{2} \mathrm{C} T_{x} / \mathrm{SiO}_{2}$ behaves very differently in reductive de-functionalization conditions when compared to $m-\mathrm{Mo}_{2} \mathrm{CT}_{x}$ that sinters under these conditions forming a porous bulk $\beta-\mathrm{Mo}_{2} \mathrm{C}$ phase ${ }^{32}$. Similarly, a multi-layer $m-\mathrm{V}_{2} \mathrm{CT}_{x}$ was reported to sinter around $600^{\circ} \mathrm{C}$, which appears to be a general temperature limitation of multi-layer MXenes $^{41}$. These results underline the importance of the dispersion of the nanosheets on a support to avoid sintering. Next, we prepared silica-supported model 2D molybdenum oxycarbide $2 \mathrm{D}-\mathrm{Mo}_{2} \mathrm{CO}_{x} / \mathrm{SiO}_{2}$ by treating $2 \mathrm{D}-\mathrm{Mo}_{2} \mathrm{C} / \mathrm{SiO}_{2}$ in a flow of $\mathrm{CO}_{2}\left(800^{\circ} \mathrm{C}, 1 \mathrm{~h}\right.$, Fig. 1a). According to TEM, the $\mathrm{CO}_{2}$ treatment of $2 \mathrm{D}-\mathrm{Mo}_{2} \mathrm{C} / \mathrm{SiO}_{2}$ does not alter the morphology or dispersion of the supported nanosheets (Supplementary Fig. 9).

A comparison of the Mo $3 d$ XPS spectra of the prepared silicasupported materials and $\beta-\mathrm{Mo}_{2} \mathrm{C}$ and $\mathrm{MoO}_{3}$ references is given in Fig. 1d. The Mo $3 d$ spectrum of $2 \mathrm{D}-\mathrm{Mo}_{2} \mathrm{CT}_{x} / \mathrm{SiO}_{2}$ was fitted with $\mathrm{Mo}^{4+}, \mathrm{Mo}^{5+}$, and $\mathrm{Mo}^{6+}$ components with the latter two being the dominating oxidation states (Supplementary Table 2). In contrast, the Mo $3 d$ spectrum of $m-\mathrm{Mo}_{2} \mathrm{CT}_{x}$ can be fitted using only $\mathrm{Mo}^{4+}$ and $\mathrm{Mo}^{5+}$ components (Supplementary Table 2$)^{32}$ indicating that Mo sites are more oxidized in the silica-supported delaminated $\mathrm{Mo}_{2} \mathrm{CT}_{x}$ nanosheets than in $m-\mathrm{Mo}_{2} \mathrm{CT}$. In contrast, the Mo $3 d$ XPS spectrum of $2 \mathrm{D}-\mathrm{Mo}_{2} \mathrm{C} / \mathrm{SiO}_{2}$ is described by mostly carbidic Mo sites in addition to a smaller fraction of $\mathrm{Mo}^{4+}$ and $\mathrm{Mo}^{6+}$ sites (Supplementary Table 2). To understand better the nature of the $\mathrm{Mo}^{4+}$ and $\mathrm{Mo}^{6+}$ sites, observed by XPS of the reduced materials, $2 \mathrm{D}-\mathrm{Mo}_{2} \mathrm{C} / \mathrm{SiO}_{2}$ was analyzed by transmission IR spectroscopy revealing a low intensity band at ca. $2290 \mathrm{~cm}^{-1}$ that is tentatively assigned to surface $[\equiv \mathrm{Si}-\mathrm{H}]$ sites (Supplementary Fig. 15). We speculate that the high temperature $\mathrm{H}_{2}$ treatment of $2 \mathrm{D}-\mathrm{Mo}_{2} \mathrm{CT}_{x} / \mathrm{SiO}_{2}$ may give molybdenum hydrides (carbidic or oxycarbidic) that further react by opening the siloxane bridges of silica forming $\left[\mathrm{Mo}-\mathrm{O}_{\mathrm{s}}\right]$ and $[\equiv \mathrm{Si}-\mathrm{H}]$ bonds (Supplementary Fig. 15, inset). Such reactivity has been observed previously for surface hydrides of tantalum that cleaved siloxane bridges of silica ${ }^{42}$. Therefore $\mathrm{Mo}^{4+}$ sites in $2 \mathrm{D}-\mathrm{Mo}_{2} \mathrm{C} / \mathrm{SiO}_{2}$ are likely formed due to the grafting 43 of the reduced nanosheets onto the silica surface.

Interestingly, the fitting of the $3 d$ XPS spectrum of Mo in 2D$\mathrm{Mo}_{2} \mathrm{CO}_{x} / \mathrm{SiO}_{2}$ requires 4 components, namely $\mathrm{Mo}^{6+}, \mathrm{Mo}^{5+}$, $\mathrm{Mo}^{4+}$ and metallic $\mathrm{Mo}^{0}$ (Supplementary Table 2). Note that $\mathrm{Mo}^{0}$ is not observed in the XPS spectra of $2 \mathrm{D}-\mathrm{Mo}_{2} \mathrm{C} / \mathrm{SiO}_{2}$ and $2 \mathrm{D}$ $\mathrm{Mo}_{2} \mathrm{CT}_{x} / \mathrm{SiO}_{2}$. We rationalize this result by a partial removal of the carbidic carbon from the $2 \mathrm{D}-\mathrm{Mo}_{2} \mathrm{C}$ layer by $\mathrm{CO}_{2}$ at $800{ }^{\circ} \mathrm{C}$ (forming 2 equiv of $\mathrm{CO}$ ) and attribute the presence of the $\mathrm{Mo}^{6+}$ component in the fit to the oxygen-rich oxycarbide phase of $2 \mathrm{D}$ $\mathrm{Mo}_{2} \mathrm{CO}_{x} / \mathrm{SiO}_{2}$. In contrast, heating multi-layer $m-\mathrm{Mo}_{2} \mathrm{CT}_{x}$ in a $\mathrm{CO}_{2}$ flow transforms it into a mixture of $\beta-\mathrm{Mo}_{2} \mathrm{C}$ and $\mathrm{MoO}_{2}$ already at ca. $5500^{\circ} \mathrm{C}$, according to our in situ XRD experiment (Supplementary Fig. 16). This result underlines again that dispersion and isolation of MXene nanosheets on a support is a critical step, prior to high temperature treatments in both reducing and oxidizing conditions, to retain the nanosheet morphology of the (oxy)carbide phase. In a sharp contrast to the stability of $2 \mathrm{D}-\mathrm{Mo}_{2} \mathrm{CO}_{x} / \mathrm{SiO}_{2}$ in an atmosphere of pure $\mathrm{CO}_{2}$ at $800{ }^{\circ} \mathrm{C}$, other supported $\mathrm{Mo}_{2} \mathrm{C}$-based catalysts yield $\mathrm{MoO}_{2}$ already in $\mathrm{CO}_{2}$-rich DRM feeds, which is the main deactivation pathway of these catalysts ${ }^{11,19}$.

Next, ex situ Mo K-edge XANES spectra of $2 \mathrm{D}-\mathrm{Mo}_{2} \mathrm{CT}_{x} / \mathrm{SiO}_{2}$, $2 \mathrm{D}-\mathrm{Mo}_{2} \mathrm{C} / \mathrm{SiO}_{2}$ and $2 \mathrm{D}-\mathrm{Mo}_{2} \mathrm{CO}_{x} / \mathrm{SiO}_{2}$ were compared (Fig. 1e). Note that the edge position is defined as the first inflection point of the XANES spectra after the pre-edge feature (where the preedge corresponds to the forbidden $1 s-4 d$ transition $)^{39}$. In agreement with XPS results, $2 \mathrm{D}-\mathrm{Mo}_{2} \mathrm{CT}_{x} / \mathrm{SiO}_{2}$ features an edge position at $20015.8 \mathrm{eV}$ that is notably higher than in $m-\mathrm{Mo}_{2} \mathrm{CT} T_{x}$ $(20010.9 \mathrm{eV})$ indicating more oxidized Mo sites in supported $\mathrm{Mo}_{2} \mathrm{CT}_{x}$ nanosheets ${ }^{32}$. The observed Mo edge energy is consistent with an average oxidation state of $2 \mathrm{D}-\mathrm{Mo}_{2} \mathrm{CT}_{x} / \mathrm{SiO}_{2}$ of ca. +5.5 (Fig. 1e, inset and Supplementary Table 1). The reduction of 2D$\mathrm{Mo}_{2} \mathrm{CT}_{x} / \mathrm{SiO}_{2}$ to $2 \mathrm{D}-\mathrm{Mo}_{2} \mathrm{C} / \mathrm{SiO}_{2}$ in $\mathrm{H}_{2}$ leads to the disappearance of the pre-edge feature, as was also observed in the in situ XANES reduction experiment, and shifts the Mo edge positions significantly to lower energies, i.e., from 20015.8 to $20000.8 \mathrm{eV}$. While the Mo K-edge position confirms the carbidic nature of $2 \mathrm{D}-\mathrm{Mo}_{2} \mathrm{C} / \mathrm{SiO}_{2}$, the white line region of the XANES spectrum of $2 \mathrm{D}-\mathrm{Mo}_{2} \mathrm{C} / \mathrm{SiO}_{2}$ differs from the spectrum of bulk $\beta-\mathrm{Mo}_{2} \mathrm{C}$ (Fig. 1e) owing to the different morphologies of these two materials. This observation corroborates the results of TEM analysis and confirms further that sintering to the bulk carbide phase did not occur during the reductive treatment of 2D$\mathrm{Mo}_{2} \mathrm{CT}_{x} / \mathrm{SiO}_{2}$. Consistent with XPS analysis, the XANES spectrum of $2 \mathrm{D}-\mathrm{Mo}_{2} \mathrm{CO}_{x} / \mathrm{SiO}_{2}$ reveals a significant shift of the Mo $K$-edge towards higher energies compared to $2 \mathrm{D}-\mathrm{Mo}_{2} \mathrm{C} / \mathrm{SiO}_{2}$ (i.e., 20015.7 vs $20000.7 \mathrm{eV}$ ), suggesting an average Mo oxidation state for $2 \mathrm{D}-\mathrm{Mo}_{2} \mathrm{CO}_{x} / \mathrm{SiO}_{2}$ between $\mathrm{Mo}^{5+}$ and $\mathrm{Mo}^{6+}$ (Fig. 1e inset, Supplementary Table 1). The XANES spectrum of 2D$\mathrm{Mo}_{2} \mathrm{CO}_{x} / \mathrm{SiO}_{2}$ displays a characteristic pre-edge feature, similarly to $2 \mathrm{D}-\mathrm{Mo}_{2} \mathrm{CT}_{x} / \mathrm{SiO}_{2}$. We conclude that all available characterization data (XANES, XPS, TEM) are consistent with a predominantly nanosheet morphology and a carbidic and oxycarbidic nature of, respectively, $2 \mathrm{D}-\mathrm{Mo}_{2} \mathrm{C} / \mathrm{SiO}_{2}$ and $2 \mathrm{D}-\mathrm{Mo}_{2} \mathrm{CO}_{x} / \mathrm{SiO}$.

Correlating catalytic activity to the surface oxygen coverage of $2 \mathrm{D}-\mathrm{Mo}_{2} \mathrm{CO}_{x}$. The catalytic activities of $2 \mathrm{D}-\mathrm{Mo}_{2} \mathrm{C} / \mathrm{SiO}_{2}$ and $2 \mathrm{D}-\mathrm{Mo}_{2} \mathrm{CO}_{x} / \mathrm{SiO}_{2}$ for the dry reforming of methane $\left(800^{\circ} \mathrm{C}, 1\right.$ bar, space velocity (SV) $1200 \mathrm{~L} \mathrm{~g}_{\mathrm{Mo}}^{-1} \mathrm{~h}^{-1}$, (weight/volume flow rate) $\mathrm{W} / \mathrm{F}=3 \mathrm{~ms} \mathrm{~g}_{\mathrm{Mo}} \mathrm{mL}^{-1}$ contact time, $1: 1 \mathrm{CO}_{2}: \mathrm{CH}_{4}$ ratio) are strikingly different (Fig. 2a). While $2 \mathrm{D}-\mathrm{Mo}_{2} \mathrm{C} / \mathrm{SiO}_{2}$ shows negligible DRM activity, $2 \mathrm{D}-\mathrm{Mo}_{2} \mathrm{CO}_{x} / \mathrm{SiO}_{2}$ is highly active with methane conversion rates of $0.42 \mathrm{~mol}\left(\mathrm{CH}_{4}\right) \mathrm{mol}(\mathrm{Mo})^{-1} \mathrm{~s}^{-1}$ after 

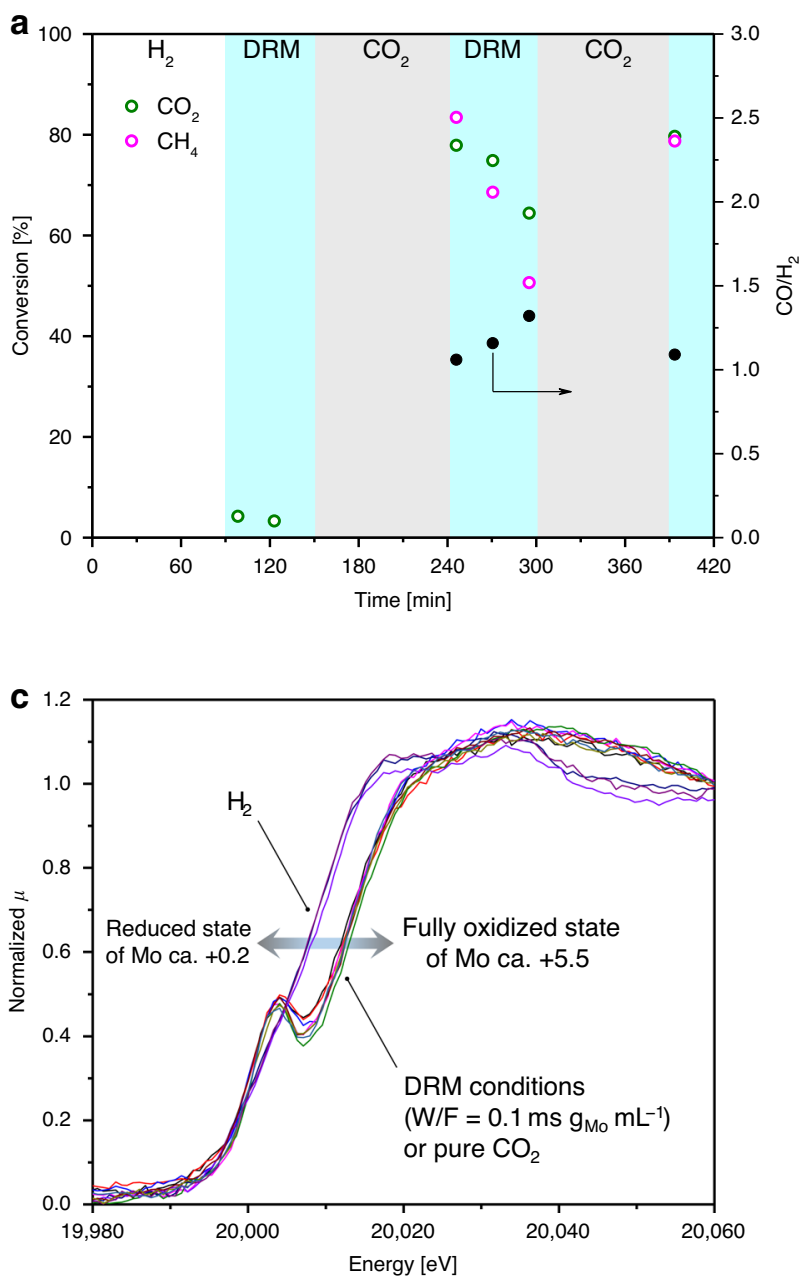

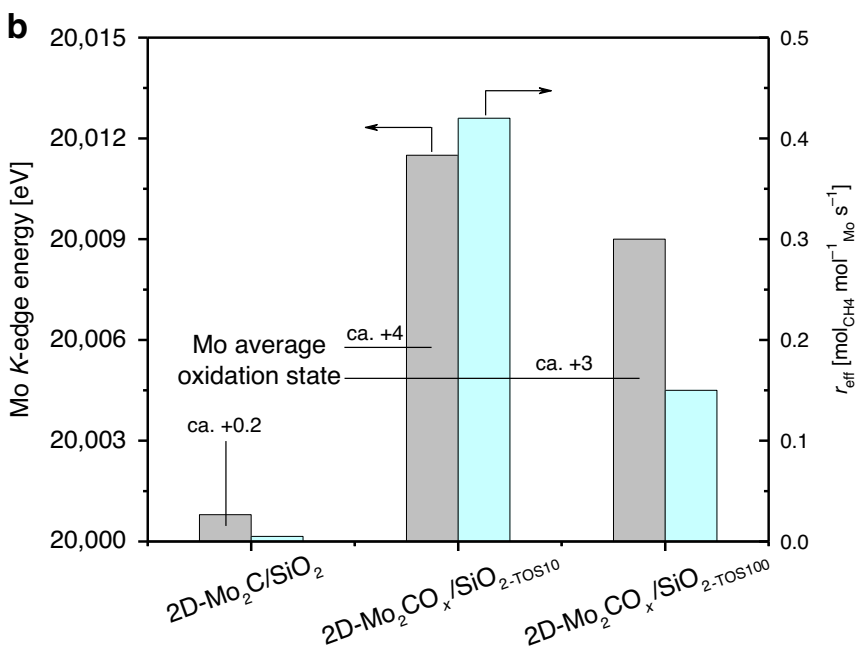

d

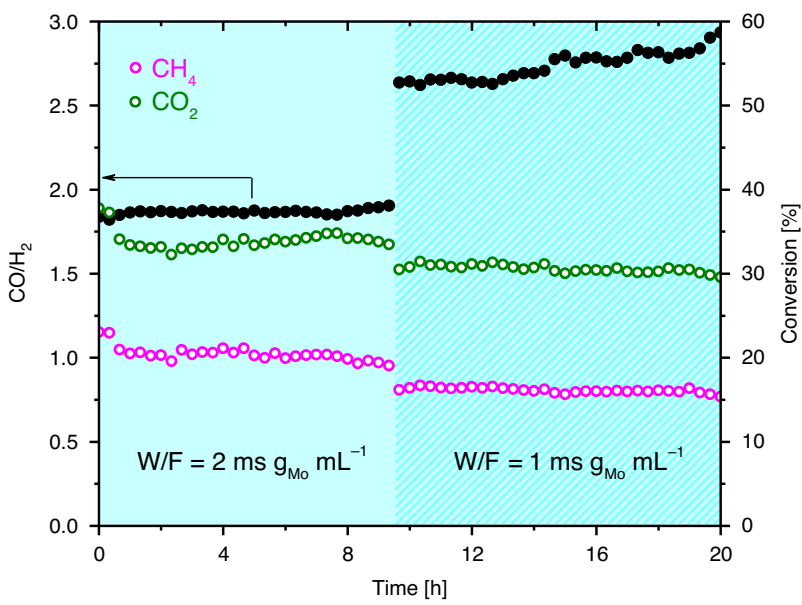

Fig. 2 Catalytic performance of $\mathbf{2 D}-\mathbf{M o}_{2} \mathbf{C O}_{\mathbf{x}} / \mathbf{S i O}_{\mathbf{2}}$ in DRM. a Catalytic performance of $2 \mathrm{D}-\mathrm{Mo}_{2} \mathrm{C} / \mathrm{SiO} \mathrm{O}_{2}(90-150 \mathrm{~min})$ and $2 \mathrm{D}-\mathrm{Mo}_{2} \mathrm{CO} \times \mathrm{O}_{x} / \mathrm{SiO} 2$

(240-300 min and from 390 min after the $\mathrm{CO}_{2}$ regeneration step) in DRM at a contact time (W/F) of $3 \mathrm{~ms}_{\mathrm{Mo}} \mathrm{mL}^{-1}$; b correlation of the Mo oxidation state, determined by Mo K-edge XANES, and the catalytic activity of the material; $\mathbf{c}$ Mo K-edge XANES spectra of $2 \mathrm{D}-\mathrm{Mo}_{2} \mathrm{CO} \times \mathrm{SiO}_{2}$ when exposed to $\operatorname{DRM}\left(0.1 \mathrm{~ms} \mathrm{~g}_{\mathrm{Mo}} \mathrm{mL}^{-1}\right.$ contact time), reductive and oxidative conditions at $730{ }^{\circ} \mathrm{C}$; $\mathbf{d}$ stable performance of $2 \mathrm{D}-\mathrm{Mo}_{2} \mathrm{CO}_{x} / \mathrm{SiO}_{2}$ at contact times of 1 or $2 \mathrm{~ms} \mathrm{~g}_{\mathrm{Mo}} \mathrm{mL}^{-1}$.

10 min on stream at $80 \% \mathrm{CH}_{4}$ conversion (i.e., ca. $10 \%$ below the thermodynamic equilibrium in those conditions, Fig. $2 \mathrm{a})^{40}$. Note that the $2 \mathrm{D}$ nature of our catalysts enables a very high utilization of Mo such that when normalized by weight of Mo, the initial methane consumption rate of $2 \mathrm{D}-\mathrm{Mo}_{2} \mathrm{CO}_{x} / \mathrm{SiO}_{2}$ is $\sim 10-200$ times higher than the rates that have been reported for other $\mathrm{Mo}_{2} \mathrm{C}$ based catalysts at similar conditions (Supplementary Table 3). The reference catalysts $\beta-\mathrm{Mo}_{2} \mathrm{C}$ and $m-\mathrm{Mo}_{2} \mathrm{CT}_{x}$ exhibit a significantly lower DRM activity in these conditions (ca. 0.0003 and $0.002 \mathrm{~mol}\left(\mathrm{CH}_{4}\right) \mathrm{mol}(\mathrm{Mo})^{-1} \mathrm{~s}^{-1}$ after ca. $5 \mathrm{~min}$ of time in stream, respectively), and deactivated entirely after $30 \mathrm{~min}$ of reaction (Supplementary Fig. 17). The $\mathrm{CO}$ chemisorption capacity was determined for in situ reduced $2 \mathrm{D}-\mathrm{Mo}_{2} \mathrm{CT}_{x} / \mathrm{SiO}_{2}$ and the reference $\beta-\mathrm{Mo}_{2} \mathrm{C}$ catalysts in order to establish if the superior catalytic performance of $2 \mathrm{D}-\mathrm{Mo}_{2} \mathrm{CT}_{x} / \mathrm{SiO}_{2}$ with respect to $\beta-\mathrm{Mo}_{2} \mathrm{C}$ (normalized per mass of $\mathrm{Mo}$ ) is due to the improved utilization of Mo atoms in the 2D-nanosheet catalyst, or due to a higher activity of the Mo sites in $2 \mathrm{D}-\mathrm{Mo}_{2} \mathrm{CT}_{x} / \mathrm{SiO}_{2}$ owing to their different structure and/or morphology, or a combination of these factors. Our results show that the estimated areal $\mathrm{CO}$ capacity in $2 \mathrm{D}-\mathrm{Mo}_{2} \mathrm{CT}_{x} / \mathrm{SiO}_{2}$ and the reference $\beta-\mathrm{Mo}_{2} \mathrm{C}$ catalysts are nearly the same (ca. 0.2 and $0.25-0.5 \mu \mathrm{mol} \mathrm{m}{ }^{-2}$, respectively; see Supplementary Table 4 and "Methods" for details). However, the measured methane conversion rate is ca. 3 orders of magnitude higher for $2 \mathrm{D}-\mathrm{Mo}_{2} \mathrm{CT}_{x} / \mathrm{SiO}_{2}$ relative to the $\beta-\mathrm{Mo}_{2} \mathrm{C}$ catalyst. These results provide strong evidence that the improved catalytic activity is due to the different nature of Mo sites in 2D-nanosheet catalyst.

When using a $\mathrm{CH}_{4}: \mathrm{CO}_{2}$ feed ratio of $1: 1$ and a contact time of $3 \mathrm{~ms} \mathrm{~g}_{\mathrm{cat}} \mathrm{L}^{-1}, 2 \mathrm{D}-\mathrm{Mo}_{2} \mathrm{CO}_{x} / \mathrm{SiO}_{2}$ continuously deactivates, with the methane consumption rate dropping within $100 \mathrm{~min}$ on stream by almost a factor of three to $0.15 \mathrm{~mol}\left(\mathrm{CH}_{4}\right) \operatorname{mol}(\mathrm{Mo})^{-1} \mathrm{~s}^{-1}$. At this point, the $\mathrm{CH}_{4}$ conversion has declined from ca. 80 to $30 \%$. However, the initial activity can be fully regenerated by subjecting the catalyst, after 100 min time on stream (TOS), to a flow of pure $\mathrm{CO}_{2}$ at $800^{\circ} \mathrm{C}$ for $1 \mathrm{~h}$. While carbide catalysts are generally not known for deactivation by coking ${ }^{10}$, we evaluated the possible deposition of carbon during the DRM catalytic test in a temperature programmed oxidation (TPO) experiment performed in a thermogravimetric analyzer (TGA) with a simultaneous detection of the off gas by mass spectrometer (MS, Supplementary Fig. 19). Noteworthy, no increase in the intensity of the $\mathrm{CO}_{2}$ peak was observed for the used catalysts after 10 and $100 \mathrm{~min}$ of reaction, $2 \mathrm{D}-\mathrm{Mo}_{2} \mathrm{CO}_{x} / \mathrm{SiO}_{2-\mathrm{TOS} 10}$ and $2 \mathrm{D}-\mathrm{Mo}_{2} \mathrm{CO}_{x} / \mathrm{SiO}_{2-\mathrm{TOS} 100}$ (note: these materials remained light gray before and after catalytic testing). Consistent with this, $2 \mathrm{D}-\mathrm{Mo}_{2} \mathrm{CO}_{x} / \mathrm{SiO}_{2-\mathrm{TO} 10}$ and $2 \mathrm{D}$ $\mathrm{Mo}_{2} \mathrm{CO}_{x} / \mathrm{SiO}_{2-\mathrm{TO} 100}$ did not lose any weight during the TPO experiment. Thus, TPO data provide strong evidence that no 
detectable carbon deposition occurred on $2 \mathrm{D}-\mathrm{Mo}_{2} \mathrm{CO}_{x} / \mathrm{SiO}_{2}$ under the experimental conditions of the DRM tests.

While the activation of metallic DRM catalysts by $\mathrm{CO}_{2}$ treatment has been reported before ${ }^{44}$, in particular through the removal of deposited carbon by gasification ${ }^{45}$, the reactivation of carbide-based DRM catalysts by $\mathrm{CO}_{2}$ is, to the best of our knowledge, unprecedented and remarkable given that $\mathrm{Mo}_{2} \mathrm{C}$ based catalysts for DRM are typically oxidized by $\mathrm{CO}_{2}$ yielding inactive $\mathrm{MoO}_{2}{ }^{11,15}$. Note that the reference materials could not be reactivated in $\mathrm{CO}_{2}$, which is explained by the formation of $\mathrm{MoO}_{2}$ layer covering the active phase (Supplementary Fig. 18). We hypothesized that the deactivation of $2 \mathrm{D}-\mathrm{Mo}_{2} \mathrm{CO}_{x} / \mathrm{SiO}_{2}$ with time on stream (Fig. 2a) occurred due to a continuous depletion of the oxygen coverage of the $\mathrm{CO}_{2}$-activated molybdenum oxycarbide surface. Therefore, to relate the decrease of the catalytic performance of our Mo oxycarbide catalyst to the oxidation state of $\mathrm{Mo}, 2 \mathrm{D}-\mathrm{Mo}_{2} \mathrm{CO}_{x} / \mathrm{SiO}_{2}$ that has been exposed for 10 or $100 \mathrm{~min}$ to DRM conditions was analyzed by XPS and XANES. The deconvolution of the Mo $3 d$ spectrum of $2 \mathrm{D}-\mathrm{Mo}_{2} \mathrm{CO}_{x} / \mathrm{SiO}_{2-\mathrm{TO}} 10$ reveals $\mathrm{Mo}^{6+}, \mathrm{Mo}^{5+}, \mathrm{Mo}^{4+}$, and carbidic Mo states with $\mathrm{Mo}^{4+}$ being the main component at $41 \%$ (Supplementary Table 2). Note that metallic Mo is absent in the fit of $2 \mathrm{D}-\mathrm{Mo}_{2} \mathrm{CO}_{x} / \mathrm{SiO}_{2-\mathrm{TOS} 10}$ in contrast to $2 \mathrm{D}-\mathrm{Mo}_{2} \mathrm{CO}_{x} / \mathrm{SiO}_{2}$ discussed above. This might be due to the facile carburization of $\mathrm{Mo}^{0}$ with time on stream or the removal of volatile Mo carbonyl species. The deconvolution of the Mo $3 d$ spectrum of $2 \mathrm{D}-\mathrm{Mo}_{2} \mathrm{CO}_{x} / \mathrm{SiO}_{2-\mathrm{TO} 100}$ reveals the same oxidation states as those found in $2 \mathrm{D}-\mathrm{Mo}_{2} \mathrm{CO}_{x} / \mathrm{SiO}_{2-\mathrm{TO} 10}$ $\left(\mathrm{Mo}^{6+}, \mathrm{Mo}^{5+}, \mathrm{Mo}^{4+}\right.$, and carbidic states, Supplementary Fig. 23). However, carbidic $\mathrm{Mo}$ is the main component in $2 \mathrm{D}-\mathrm{Mo}_{2} \mathrm{CO}_{x} /$ $\mathrm{SiO}_{2-\mathrm{TOS} 100}$ with a fitted fraction of $45 \%$ (Supplementary Table 2). This comparison of $2 \mathrm{D}-\mathrm{Mo}_{2} \mathrm{CO}_{x} / \mathrm{SiO}_{2}$ after 10 or 100 min of TOS clearly points at a reduced surface oxygen coverage and therefore a higher fraction of carbidic Mo in the less active catalyst, namely $2 \mathrm{D}-\mathrm{Mo}_{2} \mathrm{CO}_{x} / \mathrm{SiO}_{2}-\mathrm{TO} 100$. Noteworthy, similarly to the as prepared $2 \mathrm{D}-\mathrm{Mo}_{2} \mathrm{CT}_{x} / \mathrm{SiO}_{2}$, the XRD pattern of $2 \mathrm{D}$ -

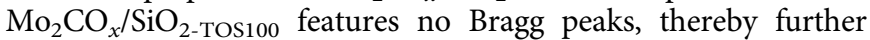
confirming that no sintering to crystalline molybdenum oxides or carbides had occurred after this time (Supplementary Fig. 6).

XANES data agree well with the XPS results as the catalyst with the highest activity $\left(2 \mathrm{D}-\mathrm{Mo}_{2} \mathrm{CO}_{x} / \mathrm{SiO}_{2-\mathrm{TO} 10}\right)$ features a Mo $\mathrm{K}$ edge position at $20011.5 \mathrm{eV}$, which corresponds to an average oxidation state of Mo of +4 (Supplementary Fig. 14 and Fig. 2b). Note that the pre-edge feature in $2 \mathrm{D}-\mathrm{Mo}_{2} \mathrm{CO}_{x} / \mathrm{SiO}_{2}$ is welldefined, but poorly resolved in $2 \mathrm{D}-\mathrm{Mo}_{2} \mathrm{CO}_{x} / \mathrm{SiO}_{2-\mathrm{TO} 10}$, suggesting a change in the geometry of the Mo sites due to the partial reduction during DRM conditions (Supplementary Fig. 14). 2D$\mathrm{Mo}_{2} \mathrm{CO}_{x} / \mathrm{SiO}_{2-\mathrm{TO} 100}$ displays a Mo $K$-edge position at 20009.0 $\mathrm{eV}$, corresponding to an average Mo oxidation state of $\mathrm{ca} .+3$. This means that $2 \mathrm{D}-\mathrm{Mo}_{2} \mathrm{CO}_{x} / \mathrm{SiO}_{2}$ does not produce any measurable amount of coke when operated under a contact time of $3 \mathrm{~ms} \mathrm{~g}_{\mathrm{Mo}} \mathrm{mL}^{-1}$ and deactivates by reduction, lowering the oxygen coverage with TOS compared to the as- $\mathrm{CO}_{2}$-treated 2D$\mathrm{Mo}_{2} \mathrm{CO}_{x} / \mathrm{SiO}_{2}$ material. Subjecting $2 \mathrm{D}-\mathrm{Mo}_{2} \mathrm{CO}_{x} / \mathrm{SiO}_{2-\mathrm{TO} 100}$ to a $\mathrm{CO}_{2}$ atmosphere $\left(800^{\circ} \mathrm{C}, 1 \mathrm{~h}\right)$ recovers the fully-oxidized $2 \mathrm{D}$ $\mathrm{Mo}_{2} \mathrm{CO}_{x} / \mathrm{SiO}_{2}$ characterized by a Mo oxidation state of ca. +5.5 , that is the same as in the as-prepared $2 \mathrm{D}-\mathrm{Mo}_{2} \mathrm{CO}_{x} / \mathrm{SiO}_{2}$ material (Supplementary Fig. 14). Likewise, the identical XANES spectra of $2 \mathrm{D}-\mathrm{Mo}_{2} \mathrm{CO}_{x} / \mathrm{SiO}_{2}$ prior to DRM testing and after a $\mathrm{CO}_{2}$-based regeneration step are also in line with a fully recovered oxygen coverage after regeneration (Fig. 2a and Supplementary Fig. 14). TEM images of the regenerated material reveal that the $2 \mathrm{D}$ $\mathrm{Mo}_{2} \mathrm{CO}_{x}$ nanosheets have a similar morphology to the initial 2D$\mathrm{Mo}_{2} \mathrm{CT}_{x}$ nanosheets as the hexagonal ordering of the Mo atoms and the characteristic scrolling of the nanosheets at the edges are still observed (Supplementary Fig. 10). Overall, these results highlight the remarkable structural stability of silica-supported $2 \mathrm{D}-\mathrm{Mo}_{2} \mathrm{CO}_{x}$ nanosheets under catalytic DRM environments as well as in an oxidative $\mathrm{CO}_{2}$ atmosphere at $800^{\circ} \mathrm{C}$.

To further interrogate the relationship between the oxygen coverage of $2 \mathrm{D}-\mathrm{Mo}_{2} \mathrm{CO}_{x} / \mathrm{SiO}_{2}$ and the catalytic activity in DRM, an in situ XANES experiment was performed (BM31, ESRF) ${ }^{46}$ in a capillary cell reactor wherein $2 \mathrm{D}-\mathrm{Mo}_{2} \mathrm{CT}_{x} / \mathrm{SiO}_{2}$ was first treated under $\mathrm{H}_{2}\left(750{ }^{\circ} \mathrm{C}, 0.5 \mathrm{~h}\right)$ to prepare $2 \mathrm{D}-\mathrm{Mo}_{2} \mathrm{C} / \mathrm{SiO}_{2}$ followed by exposing the material to DRM conditions at $730^{\circ} \mathrm{C}\left(\mathrm{CH}_{4}: \mathrm{CO}_{2}=\right.$ 1: $1, \mathrm{SV}=3 \times 10^{4} \mathrm{~L} \mathrm{~g}_{\mathrm{Mo}}{ }^{-1} \mathrm{~h}^{-1}$, contact time of $\left.0.1 \mathrm{~ms} \mathrm{~g}_{\mathrm{Mo}} \mathrm{mL}^{-1}\right)$. In those DRM conditions, an immediate oxidation of $2 \mathrm{D}-\mathrm{Mo}_{2} \mathrm{C} /$ $\mathrm{SiO}_{2}$ to $2 \mathrm{D}-\mathrm{Mo}_{2} \mathrm{CO}_{x} / \mathrm{SiO}_{2}$ occurred as indicated by a change of the Mo oxidation state from ca. +0.2 to +5 (Mo edge positions of 20000.7 and $20014.4 \mathrm{eV}$, respectively), consistent with a high oxygen coverage of the material (Supplementary Fig. 23). Monitoring the off-gas composition using a compact gas chromatograph (GC) ${ }^{47}$ shows no catalytic activity at those high oxygen coverages of $2 \mathrm{D}-\mathrm{Mo}_{2} \mathrm{CO}_{x}$. Hence, no reduction of $2 \mathrm{D}$ $\mathrm{Mo}_{2} \mathrm{CO}_{x}$ with TOS occurs at low contact times of the synchrotron experiment. The oxygen coverage of $2 \mathrm{D}-\mathrm{Mo}_{2} \mathrm{CO}_{x} / \mathrm{SiO}_{2}$ is high under those DRM conditions as a change to a $\mathrm{CO}_{2}$ flow does not affect the XANES spectra significantly (Fig. 2c and Supplementary Fig. 24). Switching to a $\mathrm{N}_{2}$ atmosphere and co-feeding ca. $5 \%$ of $\mathrm{H}_{2}$ instantly reduces Mo to the carbidic state, yielding XANES spectra similar to that of $2 \mathrm{D}-\mathrm{Mo}_{2} \mathrm{C} / \mathrm{SiO}_{2}$ (Fig. 2c). However, introducing the DRM feed re-forms immediately $2 \mathrm{D}-\mathrm{Mo}_{2} \mathrm{CO}_{x} /$ $\mathrm{SiO}_{2}$ with a Mo oxidation state of ca. +5 , inactive for the DRM. The major difference between the laboratory (Fig. 2a) and synchrotron experiments lies in the space velocity that is roughly 25 times higher in the synchrotron experiment. We conclude that while the ex situ XANES data associate the highest DRM activity of $2 \mathrm{D}-\mathrm{Mo}_{2} \mathrm{CO}_{x} / \mathrm{SiO}_{2}$ with an average Mo oxidation state of +4 and subsequent deactivation with TOS with the reduction of Mo, in situ Mo $K$-edge DRM experiment revealed that the oxycarbidic surface with a high oxygen coverage and an average oxidation state of +5 is inactive for DRM. The latter observation is consistent with the reduction of the average Mo oxidation state from +5.5 to +4 in $2 \mathrm{D}-\mathrm{Mo}_{2} \mathrm{CO}_{x} / \mathrm{SiO}_{2}$ within 10 min TOS in a laboratory DRM catalytic test $\left(\mathrm{W} / \mathrm{F}=3 \mathrm{~ms} \mathrm{~g}_{\mathrm{Mo}} \mathrm{mL}^{-1}\right)$. Note that no characteristic $\mathrm{MoO}_{2}$ features were observed with both ex and in situ XANES spectra for the catalyst after DRM catalytic tests, indicating that $2 \mathrm{D}-\mathrm{Mo}_{2} \mathrm{CO}_{x} / \mathrm{SiO}_{2}$ does not oxidize to bulk Mo oxides in the presence of both $\mathrm{CO}_{2}$ and $\mathrm{H}_{2} \mathrm{O}$ (the latter, owing to the parallel reverse water-gas shift (RWGS, $\mathrm{CO}_{2}+\mathrm{H}_{2} \leftrightarrow \mathrm{CO}+$ $\mathrm{H}_{2} \mathrm{O}$ ) reaction).

Next, we varied the contact time of the laboratory DRM experiment and found that for a contact time between 1 and $2 \mathrm{~ms}$ $\mathrm{g}_{\mathrm{Mo}} \mathrm{mL}^{-1}$, the performance of $2 \mathrm{D}-\mathrm{Mo}_{2} \mathrm{CO}_{x} / \mathrm{SiO}_{2}$ in DRM is stable over $20 \mathrm{~h}$ TOS (Fig. 2d). Note that the measured ratio of CO: $\mathrm{H}_{2}$ of ca. 2 and 3 for, respectively, 2 and $1 \mathrm{~ms} \mathrm{~g}_{\mathrm{Mo}} \mathrm{mL}^{-1}$, indicates that the RWGS reaction takes place as a side reaction under these conditions. Noteworthy, the contact times associated with a stable catalytic performance are intermediate between the contact times used in the synchrotron experiment and laboratory experiments in which catalyst deactivation occurred (ca. 0.1 and $3 \mathrm{~ms} \mathrm{~g}_{\mathrm{Mo}} \mathrm{mL}^{-1}$, respectively). This suggests that at short contact times, dissociation of $\mathrm{CO}_{2}$ proceeds fast and yields a too high oxygen coverage of the $\mathrm{Mo}_{2} \mathrm{CO}_{x}$ surface, while at high contact times $\mathrm{CH}_{4}$ and/or DRM products $\left(\mathrm{CO}\right.$ and $\mathrm{H}_{2}$ ) deplete the surface coverage of $\mathrm{Mo}_{2} \mathrm{CO}_{x}$ beyond the optimal value, leading to catalyst deactivation. Note that $2 \mathrm{D}-\mathrm{Mo}_{2} \mathrm{CO}_{x} / \mathrm{SiO}_{2}$ exhibits a high stability over $20 \mathrm{~h}$ on stream at $\mathrm{W} / \mathrm{F}=1-2 \mathrm{~ms} \mathrm{~g}_{\mathrm{Mo}} \mathrm{mL}^{-1}$ despite the presence of steam produced by the competing RWGS reaction. However, while at these conditions the selectivity and catalytic activity are stable, both values are lower than the initial (viz. TOS $=10 \mathrm{~min}$ ) activity 

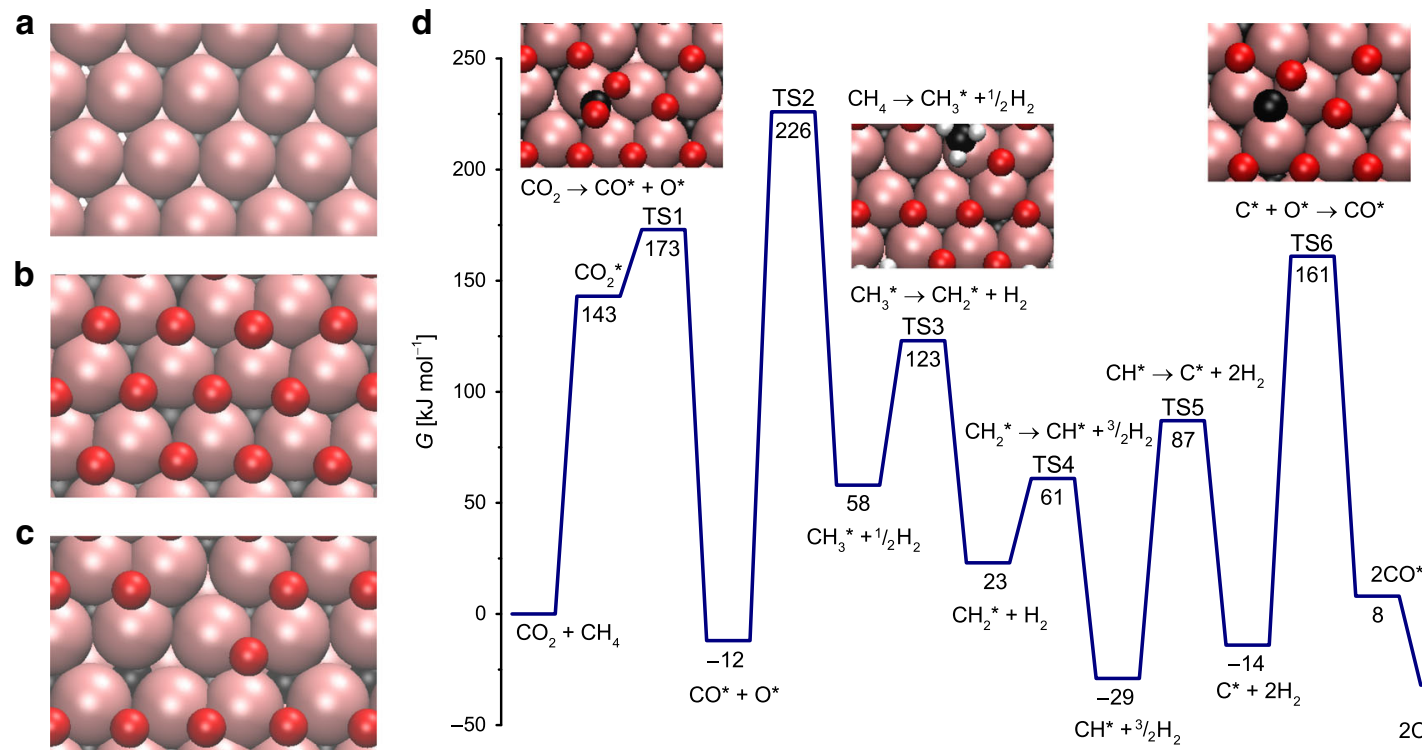

C

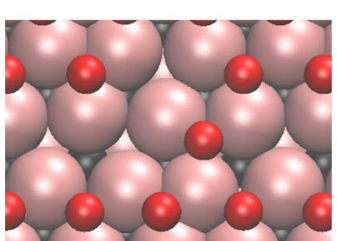

$\mathrm{CH}^{*}+{ }_{2} / 2 \mathrm{H}_{2}$

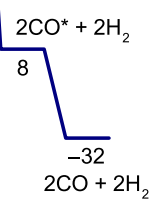

Fig. 3 Theoretical modeling of DRM pathways. Top view of the a clean $2 \mathrm{D}-\mathrm{Mo}_{2} \mathrm{C}$, b $2 \mathrm{D}-\mathrm{Mo}_{2} \mathrm{C}-1 \mathrm{O} \mathrm{ML}$ and $\mathbf{c} 2 \mathrm{D}-\mathrm{Mo}_{2} \mathrm{C}-0.67 \mathrm{O} \mathrm{ML}$ surfaces. d Gibbs free energy profile of the dry reforming of methane catalyzed by the $2 \mathrm{D}-\mathrm{Mo}_{2} \mathrm{C}-0.67 \mathrm{O} \mathrm{ML}$ surface. Gibbs energies are given with respect to initial reactants, $\mathrm{CH}_{4}$ and $\mathrm{CO}_{2}$, at $800^{\circ} \mathrm{C}$ and under 1 bar pressure. For brevity, the reaction profile is presented without $\mathrm{H}-\mathrm{H}$ coupling steps. The full profile is shown in Supplementary Fig. 25. TS stands for transition state.

and selectivity of $2 \mathrm{D}-\mathrm{Mo}_{2} \mathrm{CO}_{x} / \mathrm{SiO}_{2}$ at $\mathrm{W} / \mathrm{F}=3 \mathrm{~ms} \mathrm{~g}_{\mathrm{Mo}} \mathrm{mL}^{-1}$ (Fig. 2a, d). Our search for a stable catalytic performance with increased activity and selectivity as compared to conditions of W/ $\mathrm{F}=1-2 \mathrm{~ms}_{\mathrm{Mo}} \mathrm{mL}^{-1}$ uncovered that performing the catalytic test at a higher pressure (i.e., 8 bar instead of 1 bar) and keeping $\mathrm{W} /$ $\mathrm{F}=3 \mathrm{~ms} \mathrm{~g}_{\mathrm{Mo}} \mathrm{mL}^{-1}$ yields a $\mathrm{CO}: \mathrm{H}_{2}$ ratio close to 1.5 and only a slightly lower methane conversion rate as compared to that at 1 bar (0.42 vs $0.34 \mathrm{~mol}\left(\mathrm{CH}_{4}\right) \quad \mathrm{mol}(\mathrm{Mo})^{-1} \mathrm{~s}^{-1}$ ) (Supplementary Fig. 22). Thus, oxygen coverage higher than optimal (i.e., corresponding to an Mo oxidation state of +4 ) not only decreases the methane conversion rates, but also compromizes the selectivity due to the competing RWGS reaction.

Finally, aiming to induce major structural changes in $2 \mathrm{D}$ $\mathrm{Mo}_{2} \mathrm{CO}_{x} / \mathrm{SiO}_{2}$, we subjected the material to three subsequent DRM-catalysis- $\mathrm{CO}_{2}$-regeneration cycles with a total TOS of ca. $30 \mathrm{~h}$ using a contact time of $2 \mathrm{~ms} \mathrm{~g}_{\mathrm{Mo}} \mathrm{mL}^{-1}$ for the DRM step (Supplementary Fig. 20). Note, that the resulting material collected after the DRM step (labeled $2 \mathrm{D}-\mathrm{Mo}_{2} \mathrm{CO}_{x} / \mathrm{SiO}_{2-\text { spent }}$ ) was only partially deactivated, featuring a methane conversion rate of $0.08 \mathrm{~mol}\left(\mathrm{CH}_{4}\right) \mathrm{mol}(\mathrm{Mo})^{-1} \mathrm{~s}^{-1}$. Similarly to $2 \mathrm{D}-\mathrm{Mo}_{2} \mathrm{CO}_{x} /$ $\mathrm{SiO}_{2-\mathrm{TO} 10}$, deconvolution of the Mo $3 d$ spectrum of the spent catalyst reveals $\mathrm{Mo}^{6+}, \mathrm{Mo}^{5+}, \mathrm{Mo}^{4+}$, and carbidic Mo components, with $\mathrm{Mo}^{4+}$ being the main component at $62 \%$ (Supplementary Fig. 23 and Supplementary Table 2). TEM analysis of $2 \mathrm{D}-\mathrm{Mo}_{2} \mathrm{CO}_{x} / \mathrm{SiO}_{2-\text { spent }}$ (exposed to air) reveals the presence of 2D nanosheets with a hexagonal ordering (Supplementary Fig. 11) and overlapping signals of $\mathrm{Mo}, \mathrm{C}$, and $\mathrm{O}$ in the EDX maps, confirming the oxycarbidic nature of the catalyst. Additionally, areas containing a bulk crystalline phase of $\mathrm{MoO}_{2}$ with a distorted rutile structure were revealed by FT HR-TEM imaging (Supplementary Fig. 11), in agreement with the high fraction of $\mathrm{Mo}^{4+}$ identified in the XPS fittings of this sample and its reduced activity relative to the most active $2 \mathrm{D}-\mathrm{Mo}_{2} \mathrm{CO}_{x} / \mathrm{SiO}_{2}$-TOS10 catalyst. In agreement with TEM results, the XRD analysis of $2 \mathrm{D}-\mathrm{Mo}_{2} \mathrm{CO}_{x} / \mathrm{SiO}_{2 \text {-spent }}$ revealed small but discernable peaks corresponding to $\mathrm{MoO}_{2}$. That said, supported nanosheets remain the dominant morphology of the spent catalyst, underlining its remarkable stability.
Theoretical modeling of DRM pathways on $2 \mathrm{D}-\mathrm{Mo}_{2} \mathrm{CO}_{x} / \mathrm{SiO}_{2}$. DFT calculations provided further insight into the role of oxygen coverage for DRM activity and the energetically preferred structure of $2 \mathrm{D}-\mathrm{Mo}_{2} \mathrm{C}$ nanosheets after $\mathrm{CO}_{2}$ treatment and under DRM conditions. $2 \mathrm{D}-\mathrm{Mo}_{2} \mathrm{C}$ was modeled by three atomic layers, with two Mo layers exposed to reactants and a carbon layer in between these Mo layers (Fig. 3). The stability of the orthorhombic $\mathrm{Mo}_{2} \mathrm{C}$ and $\mathrm{Mo}_{2} \mathrm{CO}_{x}$ phases has been previously evaluated by DFT calculations ${ }^{48,49}$. We derived $2 \mathrm{D}-\mathrm{Mo}_{2} \mathrm{C}$ surface from the crystal structure of $\mathrm{Mo}_{2} \mathrm{Ga}_{2} \mathrm{C}$, slicing it along the 001 direction, since it is the most convenient approach to obtain a $2 \mathrm{D}$ system with the desired stoichiometry (Supplementary Fig. 29). The computational model used has Mo sites surrounded by three carbon atoms (Mo-C distance of $2.09 \AA$ ), with the inner layer of carbon atoms separating the Mo atoms of the top and bottom surfaces by $2.88 \AA$. The coordination number of the Mo surface atoms is 6; the Mo-Mo distances at the surface are $3.03 \AA$. Note that EXAFS fitting of $2 \mathrm{D}-\mathrm{Mo}_{2} \mathrm{CT}_{x} / \mathrm{SiO}_{2}$, as discussed above, revealed that $\mathrm{Mo}$ is coordinated with $\mathrm{O}$ and with $\mathrm{C} / \mathrm{O}$ at a distance of ca. $1.74-2.03 \AA$, which is close to the $2.09 \AA \mathrm{Mo}-\mathrm{C}$ distance of the theoretical model (Supplementary Table 3). The EXAFS analysis revealed Mo-Mo distances in the range of 2.63-3.42 $\AA$ (Table 1); this splitting of distances, as compared with the single Mo-Mo shell of the ideal model, is an indication of lattice strain in the $\mathrm{Mo}_{2} \mathrm{C} T_{x}$ sheets. We note that our idealized model does not contain lattice strain or curvature of the experimental $2 \mathrm{D}-\mathrm{Mo}_{2} \mathrm{CO}_{x} / \mathrm{SiO}_{2}$ nanosheets, and the model does not include the interaction of $2 \mathrm{D}-\mathrm{Mo}_{2} \mathrm{CO}_{x}$ with dehydroxylated $\mathrm{SiO}_{2}$ (i.e., covalent grafting observed by IR spectroscopy). Additionally, the average Mo oxidation state at one monolayer (ML) oxygen coverage of our model is lower than the experimentally determined (by XANES) Mo oxidation state for $2 \mathrm{D}-\mathrm{Mo}_{2} \mathrm{CO}_{x} / \mathrm{SiO}_{2}$ (ca. +5.5 , Fig. 1e and Supplementary Table 5). Thus, it is likely that $2 \mathrm{D}-\mathrm{Mo}_{2} \mathrm{CO}_{x} / \mathrm{SiO}_{2}$ contains more oxygen atoms than $1 \mathrm{OML}$. That being said, our idealized model is able to rationalize the experimental trends and it provides insights on the oxygen coverage (and the oxidation state of Mo), which has a significant impact on the DRM catalytic activity. Our evaluation of the 
thermodynamic stability of the different oxygen coverages of the $2 \mathrm{D}-\mathrm{Mo}_{2} \mathrm{C}$ slab at $800^{\circ} \mathrm{C}$ under $\mathrm{CO}_{2}$ reveals that a molybdenum oxycarbide phase with one oxygen monolayer (1 O ML) adsorbed on each of the Mo layers, i.e., $2 \mathrm{D}-\mathrm{Mo}_{2} \mathrm{CO}_{2}$, is preferred thermodynamically (see the Supplementary computational details for further details). $2 \mathrm{D}-\mathrm{Mo}_{2} \mathrm{CO}_{2}$ is formed from $2 \mathrm{D}-\mathrm{Mo}_{2} \mathrm{C}$ and $\mathrm{CO}_{2}$ that react yielding one oxygen atom chemisorbed on the carbide surface with a concomitant release of one gas-phase $\mathrm{CO}$ molecule. To reach this full oxygen surface coverage, $18 \mathrm{CO}_{2}$ molecules react per unit cell $\left(9 \mathrm{CO}_{2}\right.$ molecules per each side of the slab) in a highly exergonic reaction releasing Gibbs energy of $-928 \mathrm{~kJ}$ $\mathrm{mol}^{-1}$ per unit cell (ca. $-52 \mathrm{~kJ} \mathrm{~mol}^{-1}$ per $\mathrm{CO}_{2}$ molecule). The reaction of an additional $\mathrm{CO}_{2}$ molecule yields an overall Gibbs free energy of $-903 \mathrm{~kJ} \mathrm{~mol}^{-1}$, therefore, this step is unfavorable and the most stable configuration corresponds to $1 \mathrm{OML}$ coverage (i.e. one oxygen atom per Mo atom on the $2 \mathrm{D}-\mathrm{Mo}_{2} \mathrm{C}$ surface), which is in agreement with the observed stability of $2 \mathrm{D}$ $\mathrm{Mo}_{2} \mathrm{CO}_{x} / \mathrm{SiO}_{2}$ in a $\mathrm{CO}_{2}$ atmosphere at $800^{\circ} \mathrm{C}$. Under DRM conditions, the reaction of $2 \mathrm{D}-\mathrm{Mo}_{2} \mathrm{C} 1 \mathrm{O} \mathrm{ML}$ with one methane molecule has favorable energetics for the formation of one $\mathrm{CO}$ and two $\mathrm{H}_{2}$ gas-phase molecules, reducing thereby the surface oxygen coverage. Specifically, decreasing the oxygen coverage of $2 \mathrm{D}-\mathrm{Mo}_{2} \mathrm{CO}_{x}$ from a full coverage of $1 \mathrm{OML}$ to $0.89,0.78$, and $0.67 \mathrm{O}$ ML proceeds with reaction energetics of $-30,-18$ and 0 $\mathrm{kJ} \mathrm{mol}^{-1}$, that is changing from exergonic to isoergonic energetics. This data confirm that the full coverage of the surface by 1 $\mathrm{O} M L$ is thermodynamically unstable under DRM conditions, as observed experimentally.

In the following, we selected $2 \mathrm{D}-\mathrm{Mo}_{2} \mathrm{C}-0.67 \mathrm{O} \mathrm{ML}$ as a starting point to calculate the energy profile of the DRM reaction pathways since the oxygen coverage of this structure is consistent with the optimal oxygen coverage observed experimentally (characterized by an average Mo oxidation state of +4 ). This partial $0.67 \mathrm{O} \mathrm{ML}$ oxygen coverage allows for free reactive Mo sites on the surface. The energetic penalty to form $2 \mathrm{D}-\mathrm{Mo}_{2} \mathrm{C}-0.67$ $\mathrm{O}$ ML from $2 \mathrm{D}-\mathrm{Mo}_{2} \mathrm{CO}_{2}$ is merely $+30 \mathrm{~kJ} \mathrm{~mol}^{-1}$ higher than forming the most stable oxygen coverage under the DRM conditions, i.e., $2 \mathrm{D}-\mathrm{Mo}_{2} \mathrm{C}-0.88 \mathrm{O} \mathrm{ML}$. The adsorption of $\mathrm{CO}_{2}$ on $2 \mathrm{D}-\mathrm{Mo}_{2} \mathrm{C}-0.67 \mathrm{O} \mathrm{ML}$ is endergonic by $143 \mathrm{~kJ} \mathrm{~mol}^{-1}$, leading to a bent $\mathrm{CO}_{2}$ on the Mo sites of the oxycarbide surface. Dissociation of this bent $\mathrm{CO}_{2}$ to adsorbed $\mathrm{CO}^{*}$ and $\mathrm{O}^{*}$ products requires $173 \mathrm{~kJ} \mathrm{~mol}^{-1}$ of Gibbs free energy, and is overall exergonic by $12 \mathrm{~kJ} \mathrm{~mol}^{-1}$ (Fig. 3). This Gibbs energy barrier is even lower than the one obtained for a $\mathrm{Ni}(111)$ surface at $650{ }^{\circ} \mathrm{C}$ $\left(209 \mathrm{~kJ} \mathrm{~mol}^{-1}\right)^{50}$. In terms of required electronic energy, $\mathrm{CO}_{2}$ cleavage of the adsorbed, bent $\mathrm{CO}_{2}$ intermediate has a very low energy barrier of $+31 \mathrm{~kJ} \mathrm{~mol}^{-1}$. This bent $\mathrm{CO}_{2}$ adsorbate was evaluated previously on several metal carbides ${ }^{51}$ and was suggested to enhance the reactivity of $\mathrm{CO}_{2}$ on interfaces between a metal and a metal carbide ${ }^{52}$ or a metal oxide ${ }^{53-55}$. DFT calculations on the clean, Mo-terminated surface of $\delta-\mathrm{Mo}_{2} \mathrm{C}(001)$ showed that $\mathrm{CO}_{2}$ activation on molybdenum carbides is also associated with low activation barriers ${ }^{56}$. In turn, the activation of $\mathrm{CH}_{4}$ via $\mathrm{C}-\mathrm{H}$ bond cleavage requires a higher Gibbs activation energy of $242 \mathrm{~kJ} \mathrm{~mol}^{-1}$ and the reaction occurs on Mo sites of the oxycarbide surface. The calculated energy barrier is comparable to the ones computed for $\mathrm{Ni}(111), \operatorname{Pd}(111)$, and $\mathrm{Pt}(111)$ surfaces $^{50}$. Conversely, $\mathrm{CH}_{4}$ activation on oxygen sites to form ${ }^{*} \mathrm{OCH}_{3}$ and $* \mathrm{OH}$ is endergonic by $105 \mathrm{~kJ} \mathrm{~mol}^{-1}$, which is by $45 \mathrm{~kJ} \mathrm{~mol}^{-1}$ less favorable than $\mathrm{CH}_{4}$ activation on the Mo sites of the same surface.

Subsequent $\mathrm{CH}_{3}$ and $\mathrm{CH}_{2}$ activation steps to form $\mathrm{CH}_{2}{ }^{*}$ and $\mathrm{CH}^{*}$ species are significantly less energy demanding than the initial $\mathrm{C}-\mathrm{H}$ activation of $\mathrm{CH}_{4}$, with respective Gibbs energy barriers of 63 and $38 \mathrm{~kJ} \mathrm{~mol}^{-1}$. However, the cleavage of the $\mathrm{C}-\mathrm{H}$ bond in $\mathrm{CH}^{*}$ to form adsorbed $\mathrm{C}$ and $\mathrm{H}$ has a high Gibbs energy barrier of $117 \mathrm{~kJ} \mathrm{~mol}^{-1}$. Note that each successive $\mathrm{C}-\mathrm{H}$ activation of methane generates an adsorbed hydrogen that can be released as an $\mathrm{H}_{2}$ in a strongly entropically favored process, releasing 59 kcal mol ${ }^{-1}$ at $800^{\circ} \mathrm{C}$ per each desorbed $\mathrm{H}_{2}$ molecule (Fig. 3).

Besides the activation of $\mathrm{CO}_{2}$ and $\mathrm{CH}_{4}$, another key step in the dry reforming of methane is the oxidation of either $\mathrm{CH}^{*}$ or $\mathrm{C}^{*}$ species on the oxycarbide surface by adsorbed oxygen $\left(\mathrm{O}^{*}\right.$ or structural oxygen $)^{57}$ ultimately producing adsorbed $\mathrm{CO}$. In the case of $2 \mathrm{D}-\mathrm{Mo}_{2} \mathrm{CO}_{x}$, and in contrast to metallic surfaces ${ }^{50}$, the preferred mechanism is the direct oxidation of adsorbed $\mathrm{C}^{*}$ by adsorbed $\mathrm{O}^{*}$ to form CO*. This pathway has a Gibbs energy barrier of $175 \mathrm{~kJ} \mathrm{~mol}^{-1}$, and it is endergonic by only $22 \mathrm{~kJ} \mathrm{~mol}^{-1}$. The alternative pathway involving the coupling of $\mathrm{CH}^{*}$ and $\mathrm{O}^{*}$ to form adsorbed $\mathrm{CHO}^{*}$, followed by its decomposition to coadsorbed $\mathrm{CO}^{*}$ and $\mathrm{H}^{*}$, is less favorable (Supplementary Fig. 26). Finally, desorption of $\mathrm{CO}$ is exergonic by $20 \mathrm{~kJ} \mathrm{~mol}^{-1}$ per $\mathrm{CO}$ molecule. Overall, the calculated energy barriers of the proposed mechanism are feasible under the DRM conditions studied here $\left(800{ }^{\circ} \mathrm{C}, \mathrm{CH}_{4}: \mathrm{CO}_{2}=1: 1\right)$ and are thermodynamically exergonic by $32 \mathrm{~kJ} \mathrm{~mol}^{-1}$. The most energy demanding step is the initial methane activation step, which is associated with a significantly higher barrier than the direct $\mathrm{CO}_{2}$ activation or the $\mathrm{C}-\mathrm{O}$ coupling step forming $\mathrm{CO}$. In addition, the relative rates for the formation and consumption of intermediate oxygen and carbon surface species, and, therefore their ratio on the $2 \mathrm{D}$-oxycarbide surface, has to be similar in order to obtain a good catalytic performance. Our theoretical calculations suggest that the ratio of $\mathrm{C}^{*}$ to $\mathrm{O}^{*}$ is another possible factor (besides the oxidation state of Mo atoms on the surface) that can contribute to the significantly higher catalytic activity of the $2 \mathrm{D}-\mathrm{Mo}_{2} \mathrm{C}-0.67 \mathrm{O} \mathrm{ML}$ system in comparison to the clean $2 \mathrm{D}-\mathrm{Mo}_{2} \mathrm{C}$ surface.

We also evaluated the energy profile of the DRM reaction on a clean $2 \mathrm{D}-\mathrm{Mo}_{2} \mathrm{C}$ surface and found that the activation of $\mathrm{CO}_{2}$ occurs on this surface easier than on $2 \mathrm{D}-\mathrm{Mo}_{2} \mathrm{C}-0.67 \mathrm{O} \mathrm{ML}$. The produced $\mathrm{CO}^{*}$ and $\mathrm{O}^{*}$ surface species are significantly more stabilized on $2 \mathrm{D}-\mathrm{Mo}_{2} \mathrm{C}$ compared to $2 \mathrm{D}-\mathrm{Mo}_{2} \mathrm{C}-0.67 \mathrm{OML}$, featuring a lower Gibbs energy barrier for $\mathrm{CO}_{2}$ activation of $109 \mathrm{~kJ} \mathrm{~mol}^{-1}$ (compare to $173 \mathrm{~kJ} \mathrm{~mol}^{-1}$ for the $2 \mathrm{D}-\mathrm{Mo}_{2} \mathrm{C}-0.67 \mathrm{O}$ ML surface). The resulting adsorbed $\mathrm{CO}^{*}$ and $\mathrm{O}^{*}$ species are located at $-99 \mathrm{~kJ} \mathrm{~mol}^{-1}$ for the clean $2 \mathrm{D}-\mathrm{Mo}_{2} \mathrm{C}$ surface, which is significantly lower than for the $2 \mathrm{D}-\mathrm{Mo}_{2} \mathrm{C}-0.67 \mathrm{OML}$ surface $\left(-12 \mathrm{~kJ} \mathrm{~mol}^{-1}\right.$, Supplementary Fig. 27). That said, the free energy barrier for $\mathrm{CH}_{4}$ activation is very similar for both surfaces (238 vs. $243 \mathrm{~kJ} \mathrm{~mol}^{-1}$ ). Another difference with implications for the catalytic activity is the substantial stabilization of $\mathrm{CH}^{*}$ and $\mathrm{C}^{*}$ species on the $2 \mathrm{D}-\mathrm{Mo}_{2} \mathrm{C}$ surface with respect to the initial reactants. The high adsorption energy of $\mathrm{C}^{*}$ and $\mathrm{O}^{*}$ species lead to a significantly higher energy barrier for the $\mathrm{C}-\mathrm{O}$ coupling step $\left(+219 \mathrm{~kJ} \mathrm{~mol}^{-1}\right)$ on $2 \mathrm{D}-\mathrm{Mo}_{2} \mathrm{C}$, in contrast to the respective barrier on the $2 \mathrm{D}-\mathrm{Mo}_{2} \mathrm{C}-0.67 \mathrm{OML}$ surface $\left(+175 \mathrm{~kJ} \mathrm{~mol}^{-1}\right)$. This overstabilization of $\mathrm{CH}^{*}$ and $\mathrm{C}^{*}$ and $\mathrm{O}^{*}$ intermediates on a clean $2 \mathrm{D}-\mathrm{Mo}_{2} \mathrm{C}$ surface explains its lower activity for DRM. In contrast, the $2 \mathrm{D}-\mathrm{Mo}_{2} \mathrm{C}-0.67 \mathrm{O} \mathrm{ML}$ surface does not bind intermediates too strongly. Figure 4 summarizes our computational studies, which agree well with the experimental results discussed above.

To conclude, we have shown that supporting and dispersing delaminated $2 \mathrm{D}-\mathrm{Mo}_{2} \mathrm{CT}_{x}$ nanosheets on silica prevents to a large extent their thermal sintering to bulk $\mathrm{Mo}_{2} \mathrm{C}$ and $\mathrm{MoO}_{2}$ phases, paving the way for the application of $2 \mathrm{D}$ Mo-carbides and oxycarbides for high temperature heterogeneous catalysis. XANES and XPS analysis indicate that oxycarbidic $2 \mathrm{D}-\mathrm{Mo}_{2} \mathrm{CO}_{x}$ with an average Mo oxidation state of +4 is the active phase for DRM and oxidizing or reducing this state reduces the methane consumption rate. DFT calculations suggest that the rate-limiting step in the DRM on $2 \mathrm{D}-\mathrm{Mo}_{2} \mathrm{CO}_{x}$ is $\mathrm{CH}_{4}$ cleavage and that the oxygen coverage resulting from the initial $\mathrm{CO}_{2}$ activation steps 

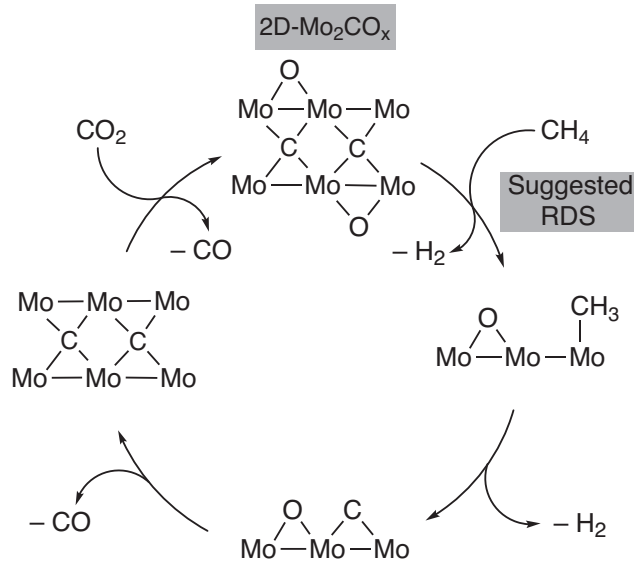

Fig. 4 A simplified proposed mechanism for the dry reforming of methane on $\mathbf{2 D}-\mathbf{M o}_{2} \mathbf{C O}_{\mathbf{x}}$. The most active catalyst has a partial oxygen surface coverage, corresponding to $\mathrm{Mo}(+4)$ oxidation state. The $\mathrm{C}-\mathrm{H}$ bond activation of methane is proposed as RDS, i.e., rate determining step, based on DFT calculations.

reduces the binding energy of $\mathrm{C}^{*}$ and $\mathrm{O}^{*}$ species and lowers, in turn, the energy barriers of the $\mathrm{C}-\mathrm{O}$ coupling step. Importantly, when deactivation by reduction of the oxygen coverage has occurred, the catalyst can be reactivated to its initial activity by reoxidation in a pure stream of $\mathrm{CO}_{2}$. Noteworthy, the nanosheet morphology of $2 \mathrm{D}-\mathrm{Mo}_{2} \mathrm{CO}_{x}$ is maintained during catalysis and regeneration. In addition, we identified hydrodynamic conditions that ensured a stable performance over $20 \mathrm{~h}$ time on stream, owing to an in situ regeneration of the optimal oxygen coverage in those conditions. Overall, the results obtained indicate that supported $2 \mathrm{D}-\mathrm{Mo}_{2} \mathrm{CO}_{x}$ is a very active and robust catalyst for high temperature catalytic applications, exhibiting a remarkable stability in oxidative environments.

\section{Methods}

Materials. Multi-layered $\mathrm{Mo}_{2} \mathrm{C} T_{x}$ material $\left(m-\mathrm{Mo}_{2} \mathrm{C} T_{x}\right)$ was synthesized following a reported method ${ }^{32} .2 \mathrm{D}-\mathrm{Mo}_{2} \mathrm{CT}_{x}$ nanosheets were delaminated from $m-\mathrm{Mo}_{2} \mathrm{CT} T_{x}$ $(50 \mathrm{mg})$ in ethanol $(10 \mathrm{~mL})$ using a pulse sonication $(1.5 \mathrm{~h}, 85 \mathrm{~W}, 20 \mathrm{kHz})$ (Fisher Scientific, FB120). Resulting suspension was centrifuged (7000 rpm, $7 \mathrm{~min}$ ) and the supernatant solution containing colloidal delaminated $\mathrm{Mo}_{2} \mathrm{CT}_{x}$ nanosheets $(d$ -

$\mathrm{Mo}_{2} \mathrm{C} T_{x}$ ) was further used for the incipient wetness impregnation (IWI) onto $\mathrm{SiO}_{2}$ support (150-300 $\mu \mathrm{m}$ particle size fraction of Aerosil 300 that had been calcined at $950^{\circ} \mathrm{C}, 194 \mathrm{~m}^{2} \mathrm{~g}^{-1}$ surface area by nitrogen physisorption). The IWI procedure using ethanol colloidal solution of $d-\mathrm{Mo}_{2} \mathrm{C} T_{x}$ was repeated multiple times and after drying $\left(100^{\circ} \mathrm{C}, 12 \mathrm{~h}\right)$ yielded $2 \mathrm{D}-\mathrm{Mo}_{2} \mathrm{CT}_{x} / \mathrm{SiO}_{2}$ material with Mo loading of 0.48 wt.\% (batch 1) and 0.35 wt.\% (batch 2 ) according to elemental analysis (ICP-AES). $2 \mathrm{D}-\mathrm{Mo}_{2} \mathrm{CT}_{x} / \mathrm{SiO}_{2}$ was subsequently reduced in hydrogen $\left(20 \mathrm{vol} \% \mathrm{H}_{2} / \mathrm{N}_{2}, 800{ }^{\circ} \mathrm{C}\right.$, $\left.1.5 \mathrm{~h}, 50 \mathrm{~mL} \mathrm{~min}^{-1}, 10^{\circ} \mathrm{C} \mathrm{min}^{-1}\right)$ and oxidized in $\mathrm{CO}_{2}\left(100 \% \mathrm{CO}_{2} 10 \mathrm{~mL} \mathrm{~min}^{-1}\right.$, $800{ }^{\circ} \mathrm{C}, 1.5 \mathrm{~h}$ ) to give $2 \mathrm{D}-\mathrm{Mo}_{2} \mathrm{C} / \mathrm{SiO}_{2}$ and $2 \mathrm{D}-\mathrm{Mo}_{2} \mathrm{CO}_{x} / \mathrm{SiO}_{2}$ materials, respectively. To avoid surface modification of the activated materials, $2 \mathrm{D}-\mathrm{Mo}_{2} \mathrm{C} / \mathrm{SiO}_{2}, 2 \mathrm{D}$ $\mathrm{Mo}_{2} \mathrm{CO}_{x} / \mathrm{SiO}_{2}$, and all activated catalysts were transferred into a nitrogen-filled glovebox $\left(\mathrm{H}_{2} \mathrm{O}\right.$ and $\mathrm{O}_{2}$ levels $\left.<0.5 \mathrm{ppm}\right)$ and handled without exposure to air.

Characterization. Ex situ XRD data were examined within the $2 \theta$ range of $5-90^{\circ}$ (step size and scan time per step were $0.0167^{\circ}$ and $3 \mathrm{~s}$, respectively). XRD data were collected on a PANalytical Empyrean X-ray diffractometer equipped with a Bragg-Brentano HD mirror and operated at $45 \mathrm{kV}$ and $40 \mathrm{~mA}$ (Cu Ka radiation, $\lambda$ $=1.5418 \mathrm{~nm}$ ). TGA was performed on Mettler Toledo TGA/DSC 3 instrument. The concentration of $2 \mathrm{D}-\mathrm{Mo}_{2} \mathrm{CT}_{x}$ flakes in the colloidal solutions was determined by drying a $750 \mu \mathrm{L}$ aliquot in a sapphire crucible $(900 \mu \mathrm{L})$ at $80^{\circ} \mathrm{C}$ for $1 \mathrm{~h}\left(5^{\circ} \mathrm{C} \mathrm{min}{ }^{-1}\right)$. TPO was performed on Mettler Toledo TGA/DSC 1 instrument. Mo material $(20 \mathrm{mg})$ was placed in an alumina crucible $(70 \mu \mathrm{L})$ and heated to $800{ }^{\circ} \mathrm{C}$ under air flow $\left(10^{\circ} \mathrm{C} \mathrm{min}^{-1}, 125 \mathrm{~mL} \mathrm{~min}^{-1}\right)$. The $\mathrm{H}_{2} \mathrm{O}$ and $\mathrm{CO}_{2}$ content in the outlet gas was followed by a mass spectrometer MKS Cirrus 3. Inductively coupled plasmaatomic emission spectroscopy (ICP-AES) analyses were performed in Remagen, Germany, by the Mikroanalytisches Labor Pascher. XPS data were acquired using a Sigma II instrument of Thermo Fisher Scientific, equipped with an UHV chamber (non-monochromatic $200 \mathrm{~W} \mathrm{Al} \mathrm{Ka}$ source, a hemispherical analyzer, and a seven channel electron multiplier, with the analyzer-to-source and the emission angles of $50^{\circ}$ of $0^{\circ}$, respectively). The survey and narrow scans used a pass energy of $50 \mathrm{eV}$ and $25 \mathrm{eV}$, respectively, and $\mathrm{C} 1 \mathrm{~s}$ peak of adventitious carbon was set at $284.8 \mathrm{eV}$ to compensate for charge induced shifts. We used a home-build air-tight cell to transfer reduced or used specimens between the glovebox and the XPS instrument ${ }^{58}$. CasaXPS Version 2.3.19PR1.0 software was used to analyze XPS data. The background was subtracted according to Shirley ${ }^{59}$, and the application of the atomic sensitivity factors (ASF) of Scofield allowed to estimate the atomic composition $^{60}$. HAADF STEM images were recorded using FEI Talos F200X with the accelerating voltage of $200 \mathrm{kV}$. All samples were prepared by shaking the holey carbon TEM grid in the vial with the dry specimen powder. $2 \mathrm{D}-\mathrm{Mo}_{2} \mathrm{C} / \mathrm{SiO}_{2}$ and $2 \mathrm{D}-\mathrm{Mo}_{2} \mathrm{CO}_{x} / \mathrm{SiO}_{2}$ were deposited on TEM grids in the glove box and transferred to the microscope without ambient exposure by using the TEM vacuum transfer holder (Fischione, 2560). FTIR Spectroscopy was conducted using a $200 \mathrm{~mL}$ glass reactor with IR-transparent $\mathrm{CaF}_{2}$ windows. A thin pellet of the sample was pressed in a glovebox and loaded to the reactor using a glass sample holder. A spectrum was recorded in an argon atmosphere in a transmission mode on a Nicolet 6700 FTIR spectrophotometer using 64 scans at a resolution of $2 \mathrm{~cm}^{-1}$. CO chemisorption was performed using an AutoChem system (Micromeritics) with a thermal conductivity detector (TCD). Approximately $100 \mathrm{mg}$ of the material was loaded in a U-shape reactor and reduced at $800{ }^{\circ} \mathrm{C}$ under $5 \% \mathrm{H}_{2} / \mathrm{Ar}$ for $1.5 \mathrm{~h}\left(10^{\circ} \mathrm{C}\right.$ $\min ^{-1}, 50 \mathrm{~mL} \mathrm{~min}^{-1}$ ). The sample was then cooled down under a He atmosphere to $450^{\circ} \mathrm{C}$ and degassed for $2 \mathrm{~h}$. The first $\mathrm{CO}$ adsorption isotherm was carried out at $50{ }^{\circ} \mathrm{C}$. The reactor was then purged with $\mathrm{He}$ for $30 \mathrm{~min}$ to remove weakly adsorbed species prior to performing the second $\mathrm{CO}$ isotherm, also at $50^{\circ} \mathrm{C}$. The amount of strongly adsorbed $\mathrm{CO}$ was determined as a difference between the first and the second adsorption isotherms, which provided the $\mathrm{CO}$ adsorption capacity. The surface area of the $2 \mathrm{D}-\mathrm{Mo}_{2} \mathrm{C}$ nanosheets in $2 \mathrm{D}-\mathrm{Mo}_{2} \mathrm{C} / \mathrm{SiO}_{2}$ was estimated based on the crystal structure of $\mathrm{Mo}_{2} \mathrm{CT}_{x}^{32}$. Considering the hexagonal ordering of the Mo atoms with a Mo-Mo distance of $2.8629 \AA$ gave an area estimate of $7.098 \AA^{2}$ per Mo atom. Based on the Mo content in $2 \mathrm{D}-\mathrm{Mo}_{2} \mathrm{CT}_{x} / \mathrm{SiO}_{2}$, determined by ICP, and the mass of the $2 \mathrm{D}-\mathrm{Mo}_{2} \mathrm{CT}_{x} / \mathrm{SiO}_{2}$ specimen used for $\mathrm{CO}$ chemisorption, the amount of strongly chemisorbed CO was normalized per the surface area of the two-dimensional molybdenum nanosheets (Supplementary Table 4).

Experiments using X-ray absorption spectroscopy (XAS) were performed at the Swiss-Norwegian Beamlines (SNBL, BM31) ${ }^{46}$ at the European Synchrotron Radiation Facility (ESRF, Grenoble, France). A double-crystal Si (111) monochromator with continuous scanning in transmission mode (unfocused beam, $1-2 \cdot 10^{9} \mathrm{ph} \mathrm{s}^{-1} \mathrm{~mm}^{-1}$ ) was used to collect XAS spectra at the Mo K-edge Edge position of the Mo foil set at $20000 \mathrm{eV}$ served for calibration of the XAS data. A quartz capillary reactor (outer diameter $1.5 \mathrm{~mm}$, wall thickness $0.1 \mathrm{~mm}$ ) was used to perform the in situ DRM experiment (Supplementary Fig. 1) ${ }^{46} \cdot 2 \mathrm{D}-\mathrm{Mo}_{2} \mathrm{CT}_{x}$ l $\mathrm{SiO}_{2}$ (ca. $2 \mathrm{mg}$ ), placed between two quartz wool plugs in a quart capillary reactor, was reduced in 20 vol\% $\mathrm{H}_{2}$ in $\mathrm{N}_{2}\left(10 \mathrm{~mL} \mathrm{~min}^{-1}\right.$ total flow rate, $50-750{ }^{\circ} \mathrm{C}$ the temperature range, $\mathrm{ca} .9^{\circ} \mathrm{C} \mathrm{min}^{-1}, 20 \mathrm{~min}$ holding time). The oxidation was performed in pure $\mathrm{CO}_{2}\left(10 \mathrm{~mL} \mathrm{~min}{ }^{-1}, 730^{\circ} \mathrm{C}, 2 \mathrm{~h}\right)$. DRM catalytic experiments were performed at $730^{\circ} \mathrm{C}$ using a mixture of $\mathrm{CH}_{4}$ and $\mathrm{CO}_{2}$ of varied ratio diluted in $\mathrm{N}_{2}\left(5 \mathrm{~mL} \mathrm{~min}{ }^{-1}\right.$ total flow rate, SV ca. $\left.30000 \mathrm{~L} \mathrm{~g}_{\mathrm{Mo}}{ }^{-1} \mathrm{~h}^{-1}\right)$. The composition of the outlet gas was followed by a portable GC (Global Analyser Solutions) with TCD and FID detectors. Ex situ XAS data were collected from pellets with an optimized amount of specimen mixed with cellulose. All reduced materials or used catalysts derived from $2 \mathrm{D}-\mathrm{Mo}_{2} \mathrm{C} / \mathrm{SiO}_{2}$ were handled in a glovebox and analyzed in an airtight sealed bags. XAS data were processed using the Athena software, and EXAFS data were fitted using the Artemis software (Demeter 0.9.25 software package) ${ }^{61}$. The edge position for $\mathrm{Mo}$ and $\mathrm{Mo}_{2} \mathrm{C}$ was defined as the position of the first maximum of the first derivative curve. The second maximum of the first derivative curve was chosen as the edge position for oxide and oxycarbide materials.

Catalytic testing. The catalytic testing of freshly-prepared materials in conditions of the dry reforming of methane was carried out in a fixed-bed quartz reactor at atmospheric pressure. In a typical experiment, $100 \mathrm{mg}$ of freshly prepared 2D$\mathrm{Mo}_{2} \mathrm{CT}_{x} / \mathrm{SiO}_{2}$ material was used. Prior to the activity tests, $2 \mathrm{D}-\mathrm{Mo}_{2} \mathrm{C} T_{x} / \mathrm{SiO}_{2}$ was in situ reduced in $20 \mathrm{vol} \% \mathrm{H}_{2} / \mathrm{N}_{2}\left(800^{\circ} \mathrm{C}, 1.5 \mathrm{~h}, 50 \mathrm{~mL} \mathrm{~min}^{-1}, 10^{\circ} \mathrm{C} \mathrm{min}{ }^{-1}\right)$ and then oxidized in pure $\mathrm{CO}_{2}\left(800^{\circ} \mathrm{C}, 1.5 \mathrm{~h}\right.$, isothermal). The activity test was then performed at $800^{\circ} \mathrm{C}$ with a variable total flow rate of the feed $\left(10-50 \mathrm{ml} \mathrm{min}^{-1}, \mathrm{SV}\right.$ $=1200-6000 \mathrm{~L} \mathrm{~g}_{\mathrm{Mo}^{-1}} \mathrm{~h}^{-1}, 45 \% \mathrm{CH}_{4}, 45 \% \mathrm{CO}_{2}$, and $\left.10 \% \mathrm{~N}_{2}\right)$. The composition of the off-gas was analyzed via a GC (PerkinElmer Clarus 580) equipped with a thermal conductivity TCD detector. The carbon balance during the catalytic tests was generally close to $100 \%$, maximal deviations noted were $\pm 10 \%$, observed when switching gases.

We note that catalytic results reported were obtained with freshly-prepared $2 \mathrm{D}$ $\mathrm{Mo}_{2} \mathrm{CT}_{x} / \mathrm{SiO}_{2}$. When as prepared $2 \mathrm{D}-\mathrm{Mo}_{2} \mathrm{CT}_{x} / \mathrm{SiO}_{2}$ was left for a prolonged time (1 month-1.5 years) in air, a complete or partial fragmentation of $2 \mathrm{D}-\mathrm{Mo}_{2} \mathrm{CT}_{x}$ nanosheets into nanoparticles had occurred according to TEM characterization (Supplementary Fig. 7). The fully fragmented material is inactive in DRM, which emphasizes the importance of 2D nanosheets morphology for the high catalytic activity.

Computational details. The Vienna Ab Initio Simulation Package (VASP) was utilized to conduct the periodic DFT calculations ${ }^{62-64}$. The projector-augmentedwave (PAW) method was used, where pseudopotentials describe interactions 
between valence electrons and ion cores while the electronic wave functions are expanded as a discrete plane wave (PW) basis set ${ }^{65}$. All calculations utilized a PW energy cutoff of $500 \mathrm{eV}$. The generalized gradient approximation (GGA), including dispersion corrections by the BEEF-vdW density functional, were used to treat electron exchange and correlation ${ }^{66}$.

The sampling of the Brillouin zone was performed using Monkhorst-Pack grids ${ }^{67}$ with K-point values equal to $3 \times 3 \times 1$ for the $\mathrm{Mo}_{2} \mathrm{C}$ surface. Electronic occupancies were determined according to a Gaussian Smearing (with a smearing value of $0.05 \mathrm{eV}$ ). Self-consistent field (SCF) calculations of the electronic structure were considered converged once the electronic energy change between two consecutive steps was below $10^{-5} \mathrm{eV}$. All geometries were optimized fully, i.e., until the forces acting on each atom were converged below $10^{-4} \mathrm{eV} \AA^{-1}$. Dipole corrections were applied in the $z$-direction and placed in the center in the unit cell. The energy of isolated molecules was determined by a $\Gamma$-point calculation such that each species was placed in a box with dimensions $15 \times 15.5 \times 16 \AA$. The climbing image nudge elastic band (CI-NEB) method allowed locating transition states (TS) using eight intermediate images ${ }^{68}$. A frequency analysis confirmed further that identified TS structures corresponded to saddle points. Normal vibration modes of adsorbed species were calculated by diagonalization of the Hessian matrix, obtained using a central finite difference approximation with displacements equal to $0.015 \AA$ in the direction of each Cartesian coordinate. All Mo and C atoms from the carbide were kept fixed during the frequency calculations of the adsorbed species. All the reported energy values in the main text correspond to Gibbs Energies at $800^{\circ} \mathrm{C}$. The theoretical model of the (001) facet of $2 \mathrm{D}-\mathrm{Mo}_{2} \mathrm{C}$ was constructed as presented in Supplementary Fig. 29. The experimental bulk structure of $\mathrm{Mo}_{2} \mathrm{Ga}_{2} \mathrm{C}$ was taken as a starting point. Then, the $\mathrm{Ga}$ atoms (in green) were removed from this structure to generate the bulk $\mathrm{Mo}_{2} \mathrm{C}$ structure. Next, an ideal 2D-facet model for $\mathrm{Mo}_{2} \mathrm{C}$ was obtained by selecting the inner fragment of the cell in the 001 direction (Supplementary Fig. 29). This was followed by the full geometry optimization of the resulting structure. The $\mathrm{Mo}_{2} \mathrm{C}(001)$ surface slab were taken with dimensions equal to $3 \times 3$, using two Mo layers on the top and the bottom of the slab and one middle carbon layer. $15 \AA$ of vacuum were added in the direction perpendicular to the surface.

\section{Data availability}

The data supporting the findings of this study are available from the corresponding authors upon reasonable request.

Received: 17 February 2020; Accepted: 31 August 2020;

Published online: 01 October 2020

\section{References}

1. Sinfelt, J. H. \& Yates, D. J. Effect of carbiding on the hydrogenolysis activity of molybdenum. Nat. Phys. Sci. 229, 27-28 (1971).

2. Levy, R. B. \& Boudart, M. Platinum-like behavior of tungsten carbide in surface catalysis. Science 181, 547-549 (1973).

3. Solymosi, F., Cserényi, J., Szöke, A., Bánsági, T. \& Oszkó, A. Aromatization of methane over supported and unsupported Mo-based catalysts. J. Catal. 165, 150-161 (1997).

4. Siaj, M., Oudghiri-Hassani, H., Maltais, C. \& McBreen, P. H. Thermally stable alkylidene groups on the surface of $\beta-\mathrm{Mo}_{2} \mathrm{C}$ : relevance to methane aromatization and olefin-metathesis catalysis. J. Phys. Chem. C. 111, 1725-1732 (2007).

5. Patt, J., Moon, D. J., Phillips, C. \& Thompson, L. Molybdenum carbide catalysts for water-gas shift. Catal. Lett. 65, 193-195 (2000).

6. Moon, D. J. \& Ryu, J. W. Molybdenum carbide water-gas shift catalyst for fuel cell-powered vehicles applications. Catal. Lett. 92, 17-24 (2004).

7. Porosoff, M. D., Yang, X., Boscoboinik, J. A. \& Chen, J. G. Molybdenum carbide as alternative catalysts to precious metals for highly selective reduction of $\mathrm{CO}_{2}$ to CO. Angew. Chem., Int. Ed. 53, 6705-6709 (2014).

8. Posada-Pérez, S. et al. The conversion of $\mathrm{CO}_{2}$ to methanol on orthorhombic $\beta$ $\mathrm{Mo}_{2} \mathrm{C}$ and $\mathrm{Cu} / \beta-\mathrm{Mo}_{2} \mathrm{C}$ catalysts: mechanism for admetal induced change in the selectivity and activity. Catal. Sci. Technol. 6, 6766-6777 (2016).

9. Hwu, H. H. \& Chen, J. G. Surface chemistry of transition metal carbides. Chem. Rev. 105, 185-212 (2005).

10. Chorkendorff, I. \& Niemantsverdriet, J. W. Concepts of Modern Catalysis and Kinetics (Wiley, 2003).

11. Claridge, J. B. et al. New catalysts for the conversion of methane to synthesis gas: molybdenum and tungsten carbide. J. Catal. 180, 85-100 (1998).

12. Schaidle, J. A., Lausche, A. C. \& Thompson, L. T. Effects of sulfur on $\mathrm{Mo}_{2} \mathrm{C}$ and $\mathrm{Pt} / \mathrm{Mo}_{2} \mathrm{C}$ catalysts: Water gas shift reaction. J. Catal. 272, 235-245 (2010).

13. Da Costa, $\mathrm{P}$. et al. Tetralin hydrogenation catalyzed by $\mathrm{Mo}_{2} \mathrm{C} / \mathrm{Al}_{2} \mathrm{O}_{3}$ and WC/ $\mathrm{Al}_{2} \mathrm{O}_{3}$ in the presence of $\mathrm{H}_{2} \mathrm{~S}$. Catal. Today 65, 195-200 (2001).

14. York, A. P. E., Claridge, J. B., Brungs, A. J., Tsang, S. C. \& Green, M. L. H. Molybdenum and tungsten carbides as catalysts for the conversion of methane to synthesis gas using stoichiometric feedstocks. Chem. Commun. 1, 39-40 (1997).

15. Brungs, A. J., York, A. P. E., Claridge, J. B., Marquez-Alvarez, C. \& Green, M. L. H. Dry reforming of methane to synthesis gas over supported molybdenum carbide catalysts. Catal. Lett. 70, 117-122 (2000).

16. Xiao, T., Wang, H., Da, J., Coleman, K. S. \& Green, M. L. H. Study of the preparation and catalytic performance of molybdenum carbide catalysts prepared with $\mathrm{C}_{2} \mathrm{H}_{2} / \mathrm{H}_{2}$ carburizing mixture. J. Catal. 211, 183-191 (2002).

17. Xiao, T.-c, Hanif, A., York, A. P. E., Nishizaka, Y. \& Green, M. L. H. Study on the mechanism of partial oxidation of methane to synthesis gas over molybdenum carbide catalyst. Phys. Chem. Chem. Phys. 4, 4549-4554 (2002).

18. LaMont, D. C., Gilligan, A. J., Darujati, A. R. S., Chellappa, A. S. \& Thomson, W. J. The effect of $\mathrm{Mo}_{2} \mathrm{C}$ synthesis and pretreatment on catalytic stability in oxidative reforming environments. Appl. Catal., A 255, 239-253 (2003).

19. LaMont, D. C. \& Thomson, W. J. Dry reforming kinetics over a bulk molybdenum carbide catalyst. Chem. Eng. Sci. 60, 3553-3559 (2005).

20. Liang, P. et al. Simple synthesis of ultrasmall $\beta-\mathrm{Mo}_{2} \mathrm{C}$ and $\alpha-\mathrm{MoC}_{1-\mathrm{x}}$ nanoparticles and new insights into their catalytic mechanisms for dry reforming of methane. Catal. Sci. Technol. 7, 3312-3324 (2017).

21. Kurlov, A. et al. Molybdenum carbide and oxycarbide from carbon-supported $\mathrm{MoO}_{3}$ nanosheets: phase evolution and DRM catalytic activity assessed by TEM and in situ XANES/XRD methods. Nanoscale 12, 13086-13094 (2020).

22. Wan, W., Tackett, B. M. \& Chen, J. G. Reactions of water and C1 molecules on carbide and metal-modified carbide surfaces. Chem. Soc. Rev. 46, 1807-1823 (2017).

23. Liu, P. \& Rodriguez, J. A. Water-gas-shift reaction on molybdenum carbide surfaces: essential role of the oxycarbide. J. Phys. Chem. B 110, 19418-19425 (2006).

24. Chen, C.-J. \& Bhan, A. $\mathrm{Mo}_{2} \mathrm{C}$ Modification by $\mathrm{CO}_{2}, \mathrm{H}_{2} \mathrm{O}$, and $\mathrm{O}_{2}$ : effects of oxygen content and oxygen source on rates and selectivity of m-cresol hydrodeoxygenation. ACS Catal. 7, 1113-1122 (2017).

25. Schaidle, J. A. et al. Experimental and computational investigation of acetic acid deoxygenation over oxophilic molybdenum carbide: surface chemistry and active site identity. ACS Catal. 6, 1181-1197 (2016).

26. Sullivan, M. M. \& Bhan, A. Effects of oxygen coverage on rates and selectivity of propane- $\mathrm{CO}_{2}$ reactions on molybdenum carbide. J. Catal. 357, 195-205 (2018).

27. Sullivan, M. M., Chen, C.-J. \& Bhan, A. Catalytic deoxygenation on transition metal carbide catalysts. Catal. Sci. Technol. 6, 602-616 (2016).

28. Lezcano-Gonzalez, I. et al. Molybdenum speciation and its impact on catalytic activity during methane dehydroaromatization in zeolite ZSM-5 as revealed by operando X-ray methods. Angew. Chem. Int. Ed. 55, 5215-5219 (2016).

29. Anasori, B., Lukatskaya, M. R. \& Gogotsi, Y. 2D metal carbides and nitrides (MXenes) for energy storage. Nat. Rev. Mater. 2, 16098 (2017).

30. Li, Z. \& Wu, Y. 2D early transition metal carbides (MXenes) for catalysis. Small 15, e1804736 (2019).

31. Zheng, Y. et al. Molybdenum oxide, oxycarbide and carbide: controlling the dynamic composition, size and catalytic activity of zeolite-supported nanostructures. J. Phys. Chem. C. 123, 22281-22292 (2019).

32. Deeva, E. B. et al. In situ XANES/XRD study of the structural stability of twodimensional molybdenum carbide $\mathrm{Mo}_{2} \mathrm{C} T_{\mathrm{x}}$ : implications for the catalytic activity in the water-gas shift reaction. Chem. Mater. 31, 4505-4513 (2019).

33. Halim, J. et al. Synthesis and characterization of 2D molybdenum carbide (MXene). Adv. Funct. Mater. 26, 3118-3127 (2016).

34. Shah, S. A. et al. Template-free $3 \mathrm{D}$ titanium carbide $\left(\mathrm{Ti}_{3} \mathrm{C}_{2} \mathrm{~T}_{\mathrm{x}}\right)$ MXene particles crumpled by capillary forces. Chem. Commun. 53, 400-403 (2017).

35. Wang, H.-W., Naguib, M., Page, K., Wesolowski, D. J. \& Gogotsi, Y. Resolving the Structure of $\mathrm{Ti}_{3} \mathrm{C}_{2} \mathrm{~T}_{\mathrm{x}}$ MXenes through multilevel structural modeling of the atomic pair distribution function. Chem. Mater. 28, 349-359 (2016).

36. Graham, P. M., Buschhaus, M. S. A., Baillie, R. A., Semproni, S. P. \& Legzdins, P. Hydroperoxide-Initiated Intramolecular Insertions of NO into metal - carbon bonds. Organometallics 29, 5068-5072 (2010).

37. Varjas, C. J., Powell, D. R. \& Thomson, R. K. Rapid access to an oxidoalkylidene complex of Mo(VI). Organometallics 34, 4806-4809 (2015).

38. Takenaka, S., Tanaka, T., Funabiki, T. \& Yoshida, S. Structures of molybdenum species in silica-supported molybdenum oxide and alkali-ionmodified silica-supported molybdenum oxide. J. Phys. Chem. B 102, 2960-2969 (1998).

39. Beale, A. M. \& Sankar, G. In situ study of the formation of crystalline bismuth molybdate materials under hydrothermal conditions. Chem. Mater. 15, 146-153 (2003).

40. Pakhare, D. \& Spivey, J. A review of dry $\left(\mathrm{CO}_{2}\right)$ reforming of methane over noble metal catalysts. Chem. Soc. Rev. 43, 7813-7837 (2014).

41. Thakur, R. et al. Insights into the thermal and chemical stability of multilayered $\mathrm{V}_{2} \mathrm{CT}_{x}$ MXene. Nanoscale 11, 10716-10726 (2019).

42. Saggio, G. et al. Synthesis, characterization, and reactivity of the highly unsaturated silica-supported trisiloxy tantalum: $(: \mathrm{SiO})_{3} \mathrm{Ta}(\mathrm{III})$ Organometallics 21, 5167-5171 (2002). 
43. Coperet, C. et al. Surface organometallic and coordination chemistry toward single-site heterogeneous catalysts: strategies, methods, structures, and activities. Chem. Rev. 116, 323-421 (2016).

44. Steib, M., Lou, Y., Jentys, A. \& Lercher, J. A. Enhanced activity in methane dry reforming by carbon dioxide induced metal-oxide interface restructuring of nickel/zirconia. ChemCatChem 9, 3809-3813 (2017).

45. Theofanidis, S. A., Batchu, R., Galvita, V. V., Poelman, H. \& Marin, G. B. Carbon gasification from $\mathrm{Fe}-\mathrm{Ni}$ catalysts after methane dry reforming. Appl. Catal., B 185, 42-55 (2016).

46. van Beek, W., Safonova, O. V., Wiker, G. \& Emerich, H. SNBL, a dedicated beamline for combined in situ X-ray diffraction, X-ray absorption and Raman scattering experiments. Phase Transit 84, 726-732 (2011).

47. Tsoukalou, A. et al. The structural evolution and dynamics of an $\operatorname{In}_{2} \mathrm{O}_{3}$ Catalyst for $\mathrm{CO}_{2}$ hydrogenation to methanol: an operando XAS-XRD and in situ TEM study. J. Am. Chem. Soc. 141, 13497-13505 (2019).

48. Medford, A. J., Vojvodic, A., Studt, F., Abild-Pedersen, F. \& Nørskov, J. K. Elementary steps of syngas reactions on Mo2C(001): adsorption thermochemistry and bond dissociation. J. Catal. 290, 108-117 (2012).

49. Likith, S. R. J. et al. Thermodynamic stability of molybdenum oxycarbides formed from orthorhombic $\mathrm{Mo}_{2} \mathrm{C}$ in oxygen-rich environments. J. Phys. Chem. C. 122, 1223-1233 (2018)

50. Foppa, L., Silaghi, M.-C., Larmier, K. \& Comas-Vives, A. Intrinsic reactivity of $\mathrm{Ni}, \mathrm{Pd}$ and $\mathrm{Pt}$ surfaces in dry reforming and competitive reactions: Insights from first principles calculations and microkinetic modeling simulations. $J$. Catal. 343, 196-207 (2016).

51. Kunkel, C., Viñes, F. \& Illas, F. Transition metal carbides as novel materials for $\mathrm{CO}_{2}$ capture, storage, and activation. Energy Environ. Sci. 9, 141-144 (2016).

52. Asara, G. G., Ricart, J. M., Rodriguez, J. A. \& Illas, F. Exploring the activity of a novel $\mathrm{Au} / \mathrm{TiC}(001)$ model catalyst towards $\mathrm{CO}$ and $\mathrm{CO}_{2}$ hydrogenation. Surf. Sci. 640, 141-149 (2015).

53. Silaghi, M.-C., Comas-Vives, A. \& Copéret, C. $\mathrm{CO}_{2}$ Activation on $\mathrm{Ni} / \gamma-\mathrm{Al}_{2} \mathrm{O}_{3}$ catalysts by first-principles calculations: from ideal surfaces to supported nanoparticles. ACS Catal. 6, 4501-4505 (2016).

54. Foppa, L. et al. Contrasting the role of $\mathrm{Ni} / \mathrm{Al}_{2} \mathrm{O}_{3}$ interfaces in water-gas shift and dry reforming of methane. J. Am. Chem. Soc. 139, 17128-17139 (2017).

55. Lam, E. et al. $\mathrm{CO}_{2}$ Hydrogenation on $\mathrm{Cu} / \mathrm{Al}_{2} \mathrm{O}_{3}$ : role of the metal/support interface in driving activity and selectivity of a bifunctional catalyst. Angew. Chem., Int. Ed. 58, 13989-13996 (2019).

56. Posada-Perez, S. et al. The bending machine: $\mathrm{CO}_{2}$ activation and hydrogenation on $\delta$-MoC $(001)$ and $\beta-\mathrm{Mo}_{2} \mathrm{C}(001)$ surfaces. Phys. Chem. Chem. Phys. 16, 14912-14921 (2014).

57. Damaskinos, C. M., Vasiliades, M. A. \& Efstathiou, A. M. The effect of $\mathrm{Ti}^{4+}$ dopant in the $5 \mathrm{wt} \% \mathrm{Ni} / \mathrm{Ce}_{1-\mathrm{x}} \mathrm{TixO}_{2-\delta}$ catalyst on the carbon pathways of dry reforming of methane studied by various transient and isotopic techniques. Appl. Catal., A 579, 116-129 (2019).

58. Cossu, G., Rossi, A., Arcifa, A. \& Spencer, N. D. Development and application of a cost-effective transfer cell for X-ray photoelectron spectroscopy. Incontro di Spettroscopia Analitica ISA Cagliari (2018).

59. Shirley, D. A. High-resolution X-ray photoemission spectrum of the valence bands of gold. Phys. Rev. B 5, 4709-4714 (1972).

60. Scofield, J. H. Hartree-slater subshell photoionization cross-sections at 1254 and $1487 \mathrm{eV}$. J. Electron Spectros. Relat. Phenom. 8, 129-137 (1976).

61. Ravel, B. \& Newville, M. ATHENA, ARTEMIS, HEPHAESTUS: data analysis for X-ray absorption spectroscopy using IFEFFIT. J. Synchrotron Rad. 12, 537-541 (2005).

62. Kresse, G. \& Hafner, J. Ab initio molecular dynamics for liquid metals. Phys. Rev. B 47, 558-561 (1993).

63. Kresse, G. \& Hafner, J. Ab initio molecular-dynamics simulation of the liquidmetal-amorphous-semiconductor transition in germanium. Phys. Rev. B 49, 14251-14269 (1994).

64. Kresse, G. \& Furthmüller, J. Efficiency of ab-initio total energy calculations for metals and semiconductors using a plane-wave basis set. Comput. Mater. Sci. 6, 15-50 (1996).

65. Blochl, P. E. Projector augmented-wave method. Phys. Rev. B 50, 17953-17979 (1994).
66. Wellendorff, J. et al. Density functionals for surface science: exchange-correlation model development with Bayesian error estimation. Phys. Rev. B 85, 235149 (2012).

67. Monkhorst, H. J. \& Pack, J. D. Special points for Brillouin-zone integrations. Phys. Rev. B 13, 5188-5192 (1976).

68. Henkelman, G., Uberuaga, B. P. \& Jónsson, H. A climbing image nudged elastic band method for finding saddle points and minimum energy paths. J. Chem. Phys. 113, 9901-9904 (2000).

\section{Acknowledgements}

The authors thank ScopeM, the Laboratory of Surface Science and Technology, the Laboratory of Surface and Interfacial Chemistry (all from ETH Zürich) for the use of their electron microscopy, XPS, and high vacuum and facilities, respectively. The European Synchrotron Radiation Facility (ESRF), through proposal CH5229, is acknowledged for provision of beamtime. Dr. Wouter van Beek and Dr. Dragos Stoian are acknowledged for the support during the XAS experiments. Dr. Agnieszka Kierzkowska, Dr. Elena Willinger and Dr. Davood Hosseini (all ETH Zürich) are acknowledged for collecting TEM data. Dr. Hui Zhou (ETH Zürich) is acknowledged for performing CO chemisorption experiments. This project has received funding from the Swiss Office of Energy (BFE; SI/500881-01), ETH Zurich (ETH-40 17-2), Spanish "Ministerio de Ciencia, Innovación y Universidades" (PGC2018-100818-A-I00; "Proyecto I+D Generación del Conocimiento"), and Spanish MEC and the European Social Fund (RyC2016-19930; "Ramon y Cajal" Fellowship to A.C.-V.).

\section{Author contributions}

D.L. and A.F. conceived the research project. A.K., A.F., and C.R.M. planned the experimental work. A.K. and E.B.D. performed catalytic tests, synthesized materials, and analyzed data. D.L., A.K., and A.T. performed TEM, XAS, and XPS experiments, respectively. P.M.A. supervised XAS experiments. A.C.-V. designed and performed DFT calculations. A.K. and A.F. wrote the original and final draft of the paper with contributions from all authors. A.F. and C.R.M. supervised the experimental research.

\section{Competing interests}

The authors declare no competing interests.

\section{Additional information}

Supplementary information is available for this paper at https://doi.org/10.1038/s41467020-18721-0.

Correspondence and requests for materials should be addressed to A.C.-V., A.F. or C.R.M.

Peer review information Nature Communications thanks the anonymous reviewer(s) for their contribution to the peer review of this work.

Reprints and permission information is available at http://www.nature.com/reprints

Publisher's note Springer Nature remains neutral with regard to jurisdictional claims in published maps and institutional affiliations.

Open Access This article is licensed under a Creative Commons Attribution 4.0 International License, which permits use, sharing, adaptation, distribution and reproduction in any medium or format, as long as you give appropriate credit to the original author(s) and the source, provide a link to the Creative Commons license, and indicate if changes were made. The images or other third party material in this article are included in the article's Creative Commons license, unless indicated otherwise in a credit line to the material. If material is not included in the article's Creative Commons license and your intended use is not permitted by statutory regulation or exceeds the permitted use, you will need to obtain permission directly from the copyright holder. To view a copy of this license, visit http://creativecommons.org/ licenses/by/4.0/.

(C) The Author(s) 2020 